Ks. Leszek MISIARCZYK (Płock)

\title{
TEOLOGIA WCIELENIA U APOLOGETÓW GRECKICH II WIEKU
}

Na początku naszej refleksji nad tajemnicą wcielenia w pismach apologetów greckich trzeba poczynić kilka uwag natury ogólnej. Otóż, analizując okres życia i twórczości pisarskiej chrześcijańskich autorów II wieku musimy ciągle pamiętać o tym, że liczne źródła z tego właśnie okresu nie dotarły niestety do naszych czasów. Wspominane przez Euzebiusza: Apologia Kwadratusa ${ }^{1}$ i Dia$\log$ między Jazonem i Papiskosem Arystona z Pelii ${ }^{2}$ przetrwały w stanie bardzo szczątkowym, natomiast dzieła Apolinarego z Hierapolis ${ }^{3}$ i Miltiadesa $^{4}$ nie zachowały się nawet fragmentarycznie. Z tekstów zaś pozostałych apologetów greckich, jeśli przyjąć za wiarygodne świadectwo Euzebiusza, posiadamy Apologię Arystydesa z Aten ${ }^{5}$, I i II Apologię oraz Dialog z Żydem Tryfonem Justyna Męczennika ${ }^{6}$, choć Euzebiusz wspomina jeszcze wiele innych zaginionych jego pism (Odprawa, O jedności Bożej, Psalmista, O duszy) ${ }^{7}$, Mowe przeciw Grekom i Diatessaron Tacjana Syryjczyka ${ }^{8}$, Prośbę za chrześcijanami

${ }^{1}$ Por. Historia Ecclesiastica (=HE) IV 3,1-3, SCh 31, 162-163, thum. A. Lisiecki, POK 3, Poznań 1924 (reprint WAM, Kraków 1993), 147-148.

${ }^{2}$ Por. HE IV 6,3, SCh 31, 165-166, POK 3, 150.

${ }^{3}$ Por. HE IV 27, SCh 31, 212, POK 3, 188. Euzebiusz wspomina tu o następujących tekstach Apolinarego: Mowa do imperatora Marka Aureliusza, Przeciwko Grekom ksiąg pięć, O prawdzie księgi dwie, Przeciwko Żydom księgi dwie.

${ }^{4}$ Por. HE V 17,5, SCh 41, 54, POK 3, 230. Według Euzebiusza Miltiades napisał ponadto: Przeciw Hellenom w dwóch księgach, Przeciw Żydom dwie księgi oraz Apologię.

${ }^{5}$ Por. HE IV 3,3, SCh 31, 162-163, POK 3, 148; rekonstrukcja tekstu greckiego z przekładem i obszernym komentarzem Apologii: Aristide di Atene, Apologia, a cura di Carlotta Alpigiano, Firenze 1988, Biblioteca Patristica 11, ss. 54-184; tłum. B. Wilanowski: „Kwartalnik Teologiczny Wileński” 1-2(1923-1924) 424-484 (wstęp + przekład), lub M. Michalski ALP I 87-91 (duże fragmenty).

${ }^{6}$ Por. Apologiae I-II, Dialogus cum Judaeo Tryphone, PG 6, 327-800, thum. A. Lisiecki, POK 4, Poznań 1926, 1-351.

${ }^{7}$ Por. HE 18,4-5, SCh 31, 195-197, POK 3, 176.

${ }^{8}$ Por. Oratio ad Graecos, PG 6, 801-888, tłum. M. Michalski ALP I 109-116; Diatessaron, CSCO 137. 
i $O$ zmartwychwstaniu umartych Atenagorasa z Aten ${ }^{9}$, Do Autolika Teofila $\mathrm{z}$ Antiochii ${ }^{10}$, niewielkie zachowane u Euzebiusza fragmenty Apologii i Homilię Paschalna Melitona $z$ Sardes $^{11}$, anonimowy List do Diogneta ${ }^{12}$, oraz Wyszydzenie filozofów pogańskich Hermiasza ${ }^{13}$. Trzeba tu też zauważyć, że chrześcijańska apologetyka grecka II wieku, ze względu na swój specyficzny charakter i kontekst historyczny w którym się rozwijała, koncentruje się raczej na przedstawianiu wiary jako swego rodzaju nowej i jedynie prawdziwej ,filozofii”. Filozofii rozumianej oczywiście bardzo szeroko, jako ars vitae. Rzadko natomiast pisarze tego okresu zajmują się osobą Jezusa historycznego czy też starają się wyjaśniać tajemnice wiary tylko na użytek wewnętrzny wspólnot chrześcijańskich. Angażują się głównie w obronę wiary chrześcijańskiej wobec zagrożeń zewnętrznych (prześladowania, zarzuty natury filozoficznej) i wewnętrznych (rodzące się herezje) niż w systematyczną refleksję czy pozytywną wykładnię teologiczną. Wśród apologetów greckich II wieku tematyką wcielenia zajmują się jedynie trzej: Arystydes w Apologii, św. Justyn Męczennik w swoich pismach i Meliton z Sardes w Homilii Paschalnej. Obecna prezentacja tej tematyki będzie się więc koncentrować tylko na tych pisarzach i na wyżej wymienionych tekstach. Choć moim zamiarem jest próba przedstawienia tematyki wcielenia u pisarzy chrześcijańskich II wieku, to jednak mam świadomość, iż z konieczności będzie to rekonstrukcja fragmentaryczna, gdyż takie są właśnie źródła z tego okresu. Pisma apologetów greckich II wieku są jednocześnie wdzięcznym i niewdzięcznym materiałem zarówno do badań nad teologią ogólną jak również nad chrześcijańską nauką o wcieleniu. Z jednej bowiem strony, tworzyli oni w okresie, gdy refleksja teologiczna Kościoła dopiero „raczkowała”, na długo przed wielkimi sporami doktrynalnymi, kiedy to krystalizowała się chrystologia i teologia trynitarna. Taka sytuacja pozostawia badaczom tego okresu w jakimś sensie większą przestrzeń dla „,interpretacyjnej wyobraźni”. Z innej jednak strony trzeba dostrzec nie mniejsze trudności. Fragmentaryczność zachowanych źródeł, często okazjonalne czy wręcz lapidarne stwierdzenia teologiczne zamiast systematycznej refleksji, prezentacja prawd wiary za pomocą terminologii i idei filozoficznych czy wręcz zupełne pomijanie niektórych kwestii teologicznych znacznie utrudniają rekonstrukcję ich myśli teologicznej.

${ }^{9}$ Por. Legatio pro christianis, De resurrectione mortuorum, PG 6, 888-1024, thum. S. Kalinkowski: Atenagoras z Aten, Prośba za chrześcijanami - O zmartwychwstaniu umartych, Warszawa 1985.

${ }^{10}$ Por. Ad Autolycum, PG 6, 1024-1168, thum. J. Czuj, POK 18, Poznań 1935, 23-120.

11 Por. De Pascha, Apologia, SCh 123, 60-126, 218-222, tłum. A. Świderkówna, BOK 10 (Pierwsi świadkowie), Kraków 1998, 308-333; Eusebius, HE 26 i V 24, POK 3, 185-188, i 239-240.

12 Por. Epistula ad Diognetum, SCh 33bis, tłum. J. Czuj, POK 18, 11-19; tłum. M. Michalski ALP I 117-121; tłum. A. Świderkówna PSP 44, 79-97, lub BOK 10, 339-348.

13 Por. Irrisio gentilium philosophorum, PG 6, 1168-1180, thum. J. Czuj, POK 18, 123-137, lub thum. M. Michalski ALP I 121-124. 
W obecnych analizach pomijam oczywiście powszechnie znany ogólny kontekst historyczny i kulturowy wczesnochrześcijańskiej apologetyki greckiej oraz podstawowe informacje dotyczące wyżej wymienionych autorów i ich dzieł. ${ }^{14}$ Odwołam się do tych elementów jedynie tam, gdzie będzie to absolutnie konieczne.

\section{NAUKA O WCIELENIU W APOLOGII ARYSTYDESA Z ATEN}

1. Problemy z Arystydesem i Apologia. Najstarszym apologetycznym tekstem chrześcijańskim zachowanym do naszych czasów, w którym pojawia się tematyka wcielenia Jezusa Chrystusa, jest Apologia Arystydesa ${ }^{15}$. Ponieważ jest to autor chrześcijański raczej niewiele znany, poświęcimy mu teraz trochę więcej miejsca. Według Euzebiusza Arystydes, podobnie zresztą jak Kwadratus, napisał swoją Apologię do cesarza Hadriana, kiedy ten ostatni przebywał w Atenach ${ }^{16}$. Kim był Arystydes? Bardzo trudno jest odpowiedzieć jednoznacznie na to pytanie, ze względu na szczupłość informacji biograficznych na jego temat. W thumaczeniu syryjskim i armeńskim Apologii sam autor przedstawia się w dedykacji dzieła jako „filozof ateński”. Niełatwo stwierdzić, czy takie określenie znajdowało się również w greckiej wersji tekstu czy też zostało dodane tylko w tłumaczeniach. Podobnie jeśli chodzi o sam ten zwrot: oznacza filozofa zawodowego czy tylko pewne ogólne przygotowanie filozoficzne? J. Geffcken twierdzi, że Arystydes nie był „zawodowym filozofem”, zaś samo określenie oznacza pewien topos charakterystyczny dla tamtej epoki. ${ }^{17}$ Takie twierdzenie oznacza, iż autor potrafi dosyć dokładnie zdefiniować pojęcie „zawodowego filozofa” chrześcijańskiego w II wieku, co wcale nie jest do końca takie oczywiste. Intuicja Geffckena może być jednak słuszna w tym sensie, że Arystydes przedstawiłby siebie jako filozofa w celu podniesienia rangi i wiarygodności swojej interwencji w sprawie chrześcijan u cesarza. Bar-

${ }^{14}$ Por. Zob. np. A. Puech, Les apologistes grecs du Ile siècle de notre ère, Paris 1912; R. M. Grant, Greek Apologists of the Second Century, Philadelphia 1988. W j. polskim istnieją niestety tylko nieliczne wprowadzenia do apologetyki greckiej, np. wstęp ks. M. Michalskiego, Antologia Literatury Patrystycznej, I, Warszawa 1975, 84-87; St. Kalinkowskiego, w: Atenagoras z Aten, Prośba za chrześcijanami. O Zmartwychwstaniu umartych, Warszawa 1985, 5-23; w: Orygenes, Przeciw Celsusowi, Warszawa 1986, 6-20; a także ogólne wprowadzenia do tłumaczonych tekstów poszczególnych autorów w: Apologeci Greccy II wieku, tłum. J. Czuj, POK 18, Poznań 1935 oraz Apologie, thum M. Szarmach - A. Świderkówna, PSP 44, Warszawa 1988, 5-17, 79-83, 99-108.

15 Na temat Arystydesa z Aten, poza krótkimi przedstawieniami podręcznikowymi i wstępami (np. B. Wilanowskiego, zob. wyżej n. 5), nie posiadamy niestety żadnych polskich obszerniejszych opracowań. Z obcojęzycznych opracowań zob. np. Aristide di Atene, Apologia, a cura di C. Alpigiano, Firenze1988, 7-51 wraz z bibliografią i omówieniem podstawowych problemów.

16 Por. HE IV 3,3, SCh 31, 162-163, POK 3, 148.

17 Por. J. Geffcken, Zwei griechische Apologeten, Leipzig 1902, s. XXXVIIIn. 
dzo trudno jest jednak zweryfikować takie przypuszczenia. Inni badacze Apologii słusznie podkreślają, że struktura pisma odpowiada dziełom filozoficznym epoki, a autor opisuje, co prawda tylko ogólnie, swoje wcześniejsze poszukiwania prawdy, być może właśnie $\mathrm{w}$ różnych nurtach filozoficznych epoki ${ }^{18}$. Niemniej jednak warto dodać, iż także ten argument jest tylko częściowo przekonujący. Dzieła filozoficzne, jak np. Apologie, również posiadały określoną ogólną strukturę, trudno więc byłoby traktować ten fakt jako argument decydujący za określeniem Arystydesa mianem zawodowego filozofa. Ostatecznie więc, $\mathrm{z}$ braku dokładniejszych informacji, przyjmuje się powszechnie, iż Arystydes był filozofem, opierając taką identyfikację na tekstach tłumaczenia armeńskiego i syryjskiego oraz informacji przekazanej nam przez Euzebiusza.

Skomplikowaną historię ma za sobą również tekst samej Apologii Arystydesa. Oryginalna, grecka wersja tekstu, nie przetrwała do naszych czasów. Pozostały jedynie dwa niewielkie fragmenty papirusów z IV wieku ${ }^{19}$. Dlatego też przez długi czas sądzono, iż Apologia całkowicie zaginęła. Gdy jednak mechitaryści z Wenecji odkryli w 1878 roku fragmenty dwóch pierwszych rozdziałów naszego tekstu w tłumaczeniu armeńskim, specjaliści uznali je zgodnie za części Apologii Arystydesa ${ }^{20}$. Nieco później w klasztorze na Synaju Rendel Harris odnalazł kompletny tekst naszej Apologii w tłumaczeniu syryjskim $^{21}$. Dzięki owym fragmentom papirusów, tłumaczeniu armeńskiemu dwóch pierwszych rozdziałów i tłumaczeniu syryjskiemu całego tekstu, udało się Robinsonowi zidentyfikować grecki tekst Apologii Arystydesa w Opowieści Barlaama i Jozafata, przekazanej w pismach św. Jana Damasceńskiego ${ }^{22}$. Rekonstrukcja greckiego tekstu Apologii, choćby ta zaproponowana przez Alpigiano, opiera się właśnie na wspomnianych fragmentach papirusów greckich z IV wieku, ${ }^{23}$ tekście z Opowieści Barlaama i Jozafata oraz tłumaczeniu syryjskim (IV w.) i armeńskim (V w.).

Nie mniejszą trudność sprawia nam również kwestia precyzyjnego określenia adresata i daty powstania Apologii Arystydesa. Według Euzebiusza i tłumaczenia armeńskiego Apologia była skierowana do cesarza Hadriana, ${ }^{24}$ natomiast wersja syryjska zawiera dwie dedykacje, jedną do Hadriana, drugą

${ }^{18}$ Tak np. włoska edytorka Carlotta Alpigiano w: Aristide di Atene, Apologia, Firenze 1988, s. 8 , przypis 2 .

${ }_{19}$ Por. Oxyrhynchos 1778 i Lit. Lond. 223, zawierające rozdz. 5-6 i 15,6-16,1.

20 Por. Mechitaristae S. Lazari, Sancti Aristidis philosophi Atheniensis sermones duo, Venetiis 1878.

${ }^{21}$ Por. J. R. Harris - J. A. Robinson, The Apology of Aristides on behalf of the Christians, Cambridge 1891.

22 Vita Barlaam et Joasaph, PG 96, 860-1240.

23 Opublikowane: P. Oxy. 1778 przez Grenfell-Hunt. The Oxyrhynchus Papyri, 15, London 1922 i P. Lit. Lond. 223 wydany przez H. T. M. Milne, A New fragment of the Apology of Aristides, JTS 25 (1923-1924) 73-74.

24 Por. „Do imperatora cesarza Hadriana od Arystydesa, filozofa ateńskiego”. 
do Antonina Piusa ${ }^{25}$. Z kolei tekst grecki odtworzony na podstawie Opowieści Barlaama i Jozafata nie zawiera żadnej dedykacji. Do kogo więc była tak naprawdę adresowana Apologia Arytydesa? Ponieważ dedykacja do Hadriana jest potwierdzona aż przez trzy źródła: Euzebiusza, tłumaczenie armeńskie i syryjskie, najprawdopodobniej pismo to było adresowane początkowo do Hadriana, a po jego śmierci sam autor dokonał zmiany adresata na Antonina Piusa. Prawdopodobnie ciągle jednak pozostawały w obiegu kopie z poprzednią dedykacją. Natomiast datę powstania Apologii Arystydesa określa się zasadniczo na podstawie świadectwa Euzebiusza, według którego autor miał to przedstawić Hadrianowi podczas jego podróży do Aten. Jeśli pamiętamy, że cesarz odbył dwie takie podróże, pierwszą w 124 lub 125 roku, drugą zaś w 129 roku, to Apologia ta powstała w okresie między ostatnimi latami panowania Hadriana a początkiem rządów Antonina Piusa, czyli pomiędzy 124 a 140 rokiem.

Apologia Arystydesa składa się z 17 rozdziałów i swoją treścią różni się znacznie od innych tekstów apologetycznych II wieku. Jej treścią nie jest bowiem typowe odpieranie różnego rodzaju zarzutów kierowanych pod adresem chrześcijan, lecz uzasadnianie wyższości religii i moralności chrześcijańskiej nad innymi religiami politeistycznymi i judaizmem. Struktura i styl pisma są bardzo proste. W rozdz. $1 \mathrm{z}$ harmonii i porządku wszechświata autor wyprowadza argument za możliwością poznania prawdziwego Boga Stwórcy i opisania Jego atrybutów: harmonia i ciągły ruch wszechświata domagają się, jego zdaniem, przyjęcia istnienia Boskiego Motoru. W kontekście monoteistycznej koncepcji Boga (rozdz. 2) Arystydes dzieli ludzkość na cztery kategorie: barbarzyńcy, Grecy, Żydzi, chrześcijanie. W dalszych rozdziałach (3-7) analizuje błędy barbarzyńców stwierdzając wyraźnie, że elementy czczone przez nich jako bóstwa, w rzeczywistości są tylko dziełami Boga. Podobnie czyni w odniesieniu do religii greckiej (rozdz. 8-11, 13) i egipskiej (rozdz. 12). Zdecydowanie pozytywniej, choć również krytycznie, wypowiada się natomiast autor o religii żydowskiej (rozdz. 14). Jedynymi, którzy zdaniem autora, znają i czczą prawdziwego Boga są tylko chrześcijanie (rozdz. 15-17). Uznają oni Boga za Stwórcę wszystkich rzeczy oraz Jego Syna jedynego i Ducha Świętego, zaś prawdziwość wiary chrześcijańskiej jest potwierdzona poprzez świadectwo czystego życia jej wyznawców. Warto także zaznaczyć, że opis życia chrześcijan bardzo przypomina ten, jaki znajdujemy w Liście do Diogneta 5-6. Zasadniczą tematykę Apologii Arystydesa można zebrać wokół takich zagadnień, jak właśnie monoteizm, podział ludzkości ze względu na kryteria religijne oraz nauka i życie chrześcijan ${ }^{26}$.

${ }^{25}$ Por. „Apologia, którą napisał Arystydes filozof, do króla Hadriana o bojaźni Bożej. Wszechmocnemu Cezarowi Tytusowi Hadrianowi Antoninowi, augustowi miłosiernemu, od Arystydesa Marcjana, filozofa ateńskiego".

26 Por. Alpigiano, Wstęp, w: Aristide di Atene, Apologia, Firenze 1988, 13-23; L. Alfonsi, La teologia della storia nell'Apologia di Aristide, ,Augustinianum” 16(1976) 37-40. 
2. Regula fidei i nauka o wcieleniu. Po przedstawieniu w rozdz. 1. swojego rozumienia prawdziwego Boga, Arystydes w oparciu o monoteistyczną definicję Boga dzieli ludzkość na trzy grupy (rozdz. 2): czciciele bożków (Chaldejczycy, Grecy i Egipcjanie), Żydzi i chrześcijanie. Dalej, w rozdz. 2, 6-8 opisuje szczegółowo wiarę chrześcijan: ten fragment tekstu jest chyba najbardziej interesujący, gdyż stanowi najprawdopodobniej najstarszą zachowaną $\mathrm{z}$ tego okresu do naszych czasów regułę wiary. Oto jej tekst:

„Chrześcijanie natomiast biorą swój początek od Pana Jezusa Chrystusa. Wyznają, że jest On Synem Boga Najwyższego, który za sprawą Ducha Świętego zstąpił z nieba dla zbawienia ludzi. Zrodzony z Dziewicy, bez udziału nasienia i nieskażony, przyjął ciało i ukazał się ludziom, aby ci odstąpili od błędu politeizmu. Chwałę zaś jego przyjścia, o królu, możesz poznać, jeśli będziesz chciał, w tym, co oni nazywają świętym pismem Ewangelii. Posiadał On dwunastu uczniów i realizując swój wspaniały plan zbawienia, z własnej woli poniósł śmierć na krzyżu według wspaniałego planu zbawienia. Po trzech dniach zmartwychwstał i wstapił do nieba. Uczniowie zaś, po Jego wniebowstąpieniu, wyruszyli do wszystkich zakątków świata i głosili Jego majestat. [W ten sposób jeden z nich przemierzył nasze regiony głosząc doktrynę prawdy]. Dlatego to właśnie ci, którzy służą nadal sprawiedliwości głoszonej przez nich, nazywani są chrześcijanami". ${ }^{27}$

Jak łatwo zauważyć, najważniejszą częścią tego tekstu są następujące słowa $(2,6)$ :

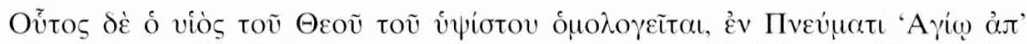

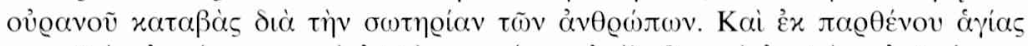

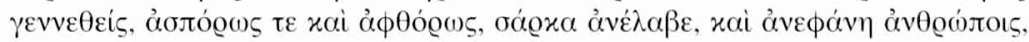

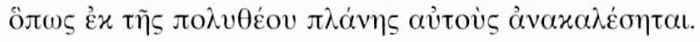

Elementy obecne w tym tekście potwierdzają wyraźnie, iż mamy przed sobą fragment wyznania wiary z II wieku, w którym jest również mowa o wcieleniu. Wiemy, że w starożytności chrześcijańskiej istniały zasadniczo dwie formuły wyznania wiary: chrystologiczna i trynitarna ${ }^{28}$. Powszechnie przyjmuje się, że ich połączenie $\mathrm{w}$ tzw. formułę syntezy, czyli trynitarne wyznanie wiary $\mathrm{z}$ rozbudowanym komma chrystologicznym, nastąpiło w połowie II wieku, ponieważ w pismach św. Justyna Męczennika odnajdujemy ślady zarówno jednej, jak i drugiej formuły. Przedstawiony powyżej tekst Arystydesa wskazuje, iż powstanie takiej formuły syntezy mogło mieć miejsce już na przełomie lat 20

27 Apologia 2,6-8, wyd. C. Alpigiano, s. 60-61, przekład własny, chyba że jest zaznaczony inny.

28 Szerzej o wyznaniach wiary por. R. Knapiński (red.), Symbol Apostolski w nauczaniu i sztuce Kościota do Soboru Trydenckiego, Lublin 1997; B. Sesboüé - J. Woliński, Bóg Zbawienia, Kraków 1999, na temat reguły wiary s. 41-62, na temat reguł i symboli wiary s. 63-120. Autorzy wymieniają co prawda różne modele chrystologiczne, model binarny (Bóg Ojciec, Chrystus) oraz trynitarny (Ojciec, Syn, Duch), lecz dają się one sprowadzić zasadniczo do dwóch podstawowych: chrystologiczny i trynitarny. 
i 30 II wieku. I choć ze struktury tekstu wynika, iż reguła wiary przedstawiona przez naszego apologetę posiada zasadniczo charakter chrystologiczny, niemniej jednak wzmiankowany jest również Bóg Najwyższy i Duch Święty. Arystydes podkreśla, iż chrześcijanie wierzą, że Jezus Chrystus jest Synem Boga Najwyższego i że właśnie wiara w bóstwo Chrystusa jest elementem konstytutywnym tożsamości chrześcijańskiej. Warto także dodać, że relację Chrystusa z Bogiem Najwyższym autor ujmuje w kategoriach synostwa, zaś działanie Ducha Świętego umieszcza już w kontekście wcielenia. Nie nazywa Boga Ojcem ani Wszechmogącym, jak to uczyni kilkadziesiąt lat później Justyn, nie mówi też nic o bóstwie Ducha Świętego. Brak ostatniego elementu nie dziwi jednak w kontekście teologicznym II wieku, natomiast nieobecność terminów „Ojciec” czy „Wszechmogący” potwierdza, iż także formuły wyznania wiary podlegały w tym okresie nieznacznej formalnej fluktuacji. Powiedzmy nawet więcej, formuła syntezy wiary, obecna w Apologii Arystydesa, nie jest typową strukturą syntezy jakie znamy z tego okresu lub późniejszych, tzn. art. 1. wyznanie wiary w Boga Ojca, art. 2 wyznanie wiary w Syna Bożego wraz z rozbudowanym komma chrystologicznym, art. 3. wyznanie wiary w Ducha Świętego ${ }^{29}$. Regula fidei obecna w Apologii Arystydesa umieszcza w miejscu centralnym niewątpliwie osobę Jezusa Chrystusa, Syna Bożego dlatego, ponieważ autor opisywał właśnie chrześcijan i ich wiarę. Pamiętamy jednak ciągle, że wzmiankuje również Boga i Ducha Świętego W tej właśnie regule wiary znajdujemy również naukę o wcieleniu, której przyjrzymy się teraz szczegółowo.

Jezus Chrystus jest Synem Bożym, który „za sprawą Ducha Świętego

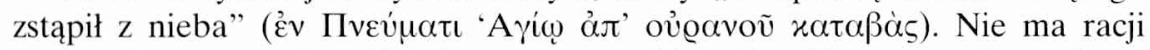
Kelly, gdy proponuje widzieć w naszym tekście dowód na tzw. chrystologię pneumatologiczną, tłumacząc go w następujący sposób: „wyznaje się, iż ten

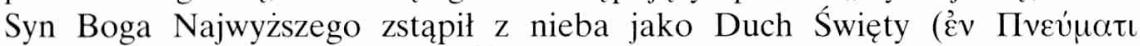
"A $\gamma(\omega)$ i wziął ciało z Dziewicy". ${ }^{30}$ Według niego, Arystydes, podobnie zresztą jak niektórzy Ojcowie Apostolscy, byłby przekonany, ze termin Duch Święty jest określeniem preegzystującego Syna, który w Chrystusie człowieku przyjął ciało z Maryi. ${ }^{31}$ 'Ev przyjmuje jednak tutaj wyraźnie sens instrumentalny, aby podkreślić właśnie rolę Ducha Świętego jako czynnego uczestnika w dziele

29 Jak choćby Symbol chrzcielny w formie pytań przekazany nam przez Tradycję Apostolska (21) Hipolita: „Czy wierzysz w Boga Ojca wszechmogącego? - Wierzę. - Czy wierzysz w Chrystusa Jezusa, Syna Bożego, który przez Ducha Świętego narodził się z Maryi Dziewicy, został ukrzyżowany pod Poncjuszem Piłatem, umarł i zmartwychwstał trzeciego dnia żywy spośród umarłych, stąpił do nieba i zasiadł po prawicy Ojca; który przyjdzie sądzić żywych i umarłych? - Wierzę. Czy wierzysz w Ducha Świętego w Świętym Kościele? - Wierzę" (tekst w SCh 11 bis, 85-97, komentarz B. Sesboüé - J. Woliński, Bóg Zbawienia, dz. cyt. s. 80-82).

${ }^{30}$ J. N. D. Kelly, Początki doktryny chrześcijańskiej, thum. J. Mrukówna, Warszawa 1988, 115.

31 Zob. słuszną krytykę we wstępie C. Alpigiano, dz. cyt., s. 25, przypis 41. 
wcielenia $^{32}$, dokładnie tak, jak thumaczymy to po polsku: „za sprawą Ducha Świętego"; nie może więc posiadać znaczenia ,jako".

Pierwszym etapem tajemnicy wcielenia jest zstąpienie Chrystusa z nieba na

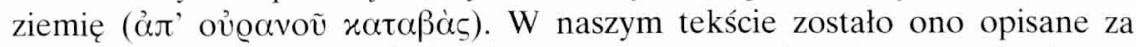
pomocą czasownika $x \alpha \tau \alpha \beta \alpha i v \omega$ i jest wyraźnym nawiązaniem do tekstów nowotestamentalnych opisujących misję Jezusa ${ }^{33}$. W Ewangelii Janowej Jezus w rozmowie z Nikodemem używa tego samego czasownika właśnie dla pod-

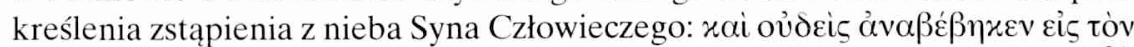

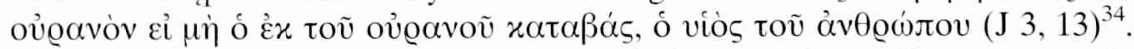
Natomiast w Ef 4, 9-10, nawet jeśli lekcja jest wątpliwa, Chrystus zostaje określony wręcz terminem technicznym jako ó $x \alpha \tau \alpha \beta \dot{\alpha} \varsigma^{35}$. Termin ó $\varkappa \alpha \tau \alpha \beta a ̀ \varsigma$ byłby więc swego rodzaju tytułem chrystologicznym. Choć nie pojawia się on dosłownie w takiej formie w tekście Arystydesa, konotacje treściowe z jego funkcją w Nowym Testamencie są wystarczająco wyraźne. W pismach Ojców Apostolskich termin ten pojawia się co prawda kilkakrotnie, lecz zawsze poza kontekstem chrystologicznym ${ }^{36}$. Warto wreszcie dodać, iż wzmianka o zstąpieniu $z$ nieba jest obecna także w wersji syryjskiej i armeńskiej naszego tekstu. Widzimy więc wyraźnie, że Arystydes odwołując się tutaj do terminologii Nowego Testamentu w opisie tajemnicy wcielenia, nie tworzy sam, lecz przytacza (dokonując zapewne transpozycji na początku tekstu) istniejącą już prawdopodobnie w jego czasach regułę wiary, utworzoną w oparciu o teksty

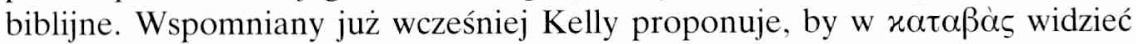
wyznanie preegzystencji Chrystusa. Myślę, że autor ten zbytnio rozdziela elementy wiary chrześcijańskiej. Termin $x \alpha \tau \alpha \beta a ̀ \varsigma$ wyraża, moim zdaniem, zarówno preegzystencję, jak i wcielenie Syna Bożego. Gdyby On był tylko człowiekiem, nie byłoby żadnego zstąpienia ani wcielenia. Zstąpienie preegzystującego Syna jest właśnie pierwszym etapem wcielenia.

Ważnym elementem wyznania wiary Arystydesa jest soteriologiczna celowość wcielenia. Syn Boży zstępuje na ziemię by wypełnić bardzo określoną

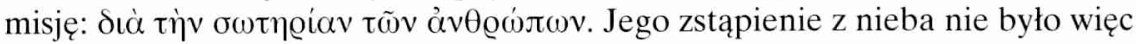
tylko rodzajem sztuki dla sztuki, ale uczynił to, by z jednej strony wypełnić

32 Por. F. Blass - A. Debrunner, Grammatica del greco del Nuovo Testamento, Brescia 1982, 281-282.

33 Por. R. Popowski, Wielki Stownik Grecko-Polski Nowego Testamentu, Warszawa 1997, 320.

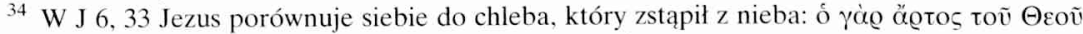

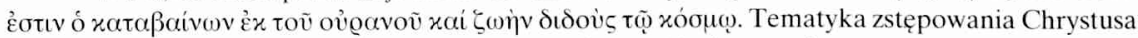

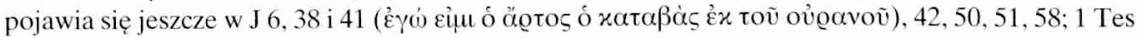
4, 16; Jk 1, 17; Ap 3, 12; por. W. F. Moulton - A. S. Geden - H. K. Moulton, A Concordance to the Greek Testament, Edinburgh 1986, 531-532.

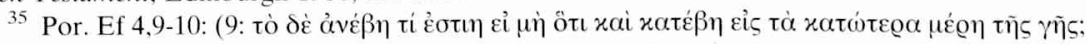

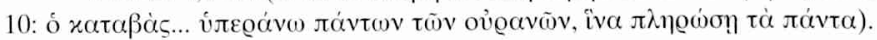

${ }^{36}$ Por. E. Goodspeed, Index patristicus sive Clavis Patrum Apostolicorum operum, Peabody $1993,118$. 
Boży „wspaniały plan zbawienia” ( $(\alpha \alpha$ ' oixovouiav $\mu \varepsilon \gamma \alpha \dot{\lambda} \eta v)$ (w. 8), z drugiej zaś, z miłości do człowieka, aby go zbawić. Arystydes nie precyzuje jeszcze w tym momencie dokładniej, na czym to zbawienie miałoby polegać, choć pośrednio komentuje to na zakończenie w. 6, ,, aby odstąpili od błędu politeiz-

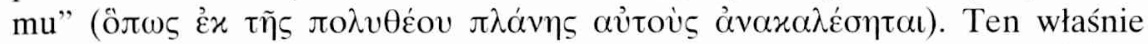
element mógłby wskazywać na dostosowanie przez Arystydesa reguły wiary do wymogów środowiska filozoficznego, do którego się zwracał oraz argumentacji przeciw politeizmowi. Choć i tutaj powinniśmy być ostrożni. Formulacja, to prawda, jest typowo filozoficzna, jednak idea jest zasadniczo biblijna: Syn Boży zstąpił za sprawą Ducha Świętego z nieba po to, aby ludzie zostali zbawieni i poznali Ojca. Dla Arystydesa zbawienie oznacza odstąpienie od błędu politeizmu i poznanie Jednego Boga. A to jest przecież dobrze znaną myślą biblijną, obecną choćby w Ewangelii Janowej: „A to jest życie wieczne: aby znali Ciebie, jedynego prawdziwego Boga, oraz Tego, którego posłałeś, Jezusa Chrystusa" (J 17, 2).

Dalsze słowa naszej reguły wiary opisują już bezpośrednio tajemnicę wcie-

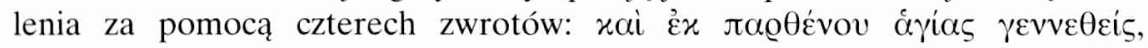

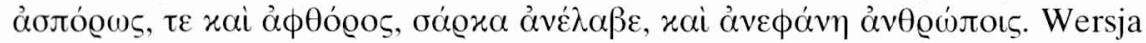
syryjska i armeńska odbiegają nieco od greckiej. W tłumaczeniu syryjskim czytamy:

„Chrześcijanie wreszcie wzięli swą religię od Jezusa Chrystusa, którego nazywają Synem Bożym, głosząc, że to sam Bóg zstąpił z nieba na ziemię i wziąwszy ciało z dziewicy hebrajskiej, zamieszkał jako Syn Boży w jednej z córek ludzkich [...]. Tenże Jezus narodził się więc z rodu żydowskiego..."37.

\section{Natomiast w wersji armeńskiej czytamy:}

„Chrześcijanie biorą pochodzenie od Pana Jezusa Chrystusa. On jest Synem Boga Najwyższego, ukazany przez Ducha Świętego, zstąpił z nieba i narodził się z dziewicy żydowskiej; przyjął ciało od dziewicy i objawił się naszej ludzkiej naturze jako Syn Boży [...]. On jest tym, który według ciała narodził się z rodu Żydów, ze Swiętej Dziewicy Maryi, Matki Boga"38.

Porównując wszystkie trzy wersje, odnosi się wrażenie, że thumaczenie armeńskie jest chyba najbardziej rozbudowane, zaś dodatek o Maryi, Matce Boga, jest niewątpliwie późniejszy. Ponieważ solidne analizy można poczynić tylko na tekstach oryginalnych, dalsze nasze refleksje będą oparte na tekście greckim, zrekonstruowanym przez Alpigiano. Pierwszy zwrot éx $\pi \alpha \varrho \theta \dot{v} v o v$

${ }^{37}$ Apologia 2, 6 i 8, thum. M. Michalski, ALP I 88. Wszystko wskazuje na to, że tłumaczenie ks. Michalskiego oparte jest na tłumaczeniu syryjskim, ale i tutaj widoczne są pewne drobne rozbieżności. Szczerze mówiąc, nie bardzo wiadomo, co było podstawą tłumaczenia.

38 Apologia [wersja armeńska] 2, 6, i 8, thum. z włoskiego (wyd. C. Alpigiano, Aristide, Apologia, dz. cyt. s. 187-188). 


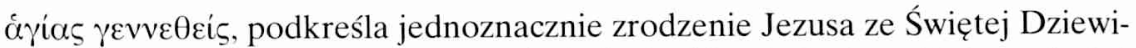
cy. Nie wzmiankuje tu jednak wcale imienia Maryi choć znajdujemy je już w Liście do Trallan $(9,1)$ Ignacego Antiocheńskiego ${ }^{39}$. Co ciekawe, zwrot $\gamma \varepsilon v v \varepsilon \theta \varepsilon i \zeta$ nawiązywałby tutaj raczej do zapowiedzi narodzin Jezusa przekaza-

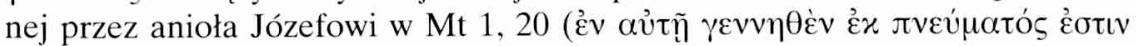

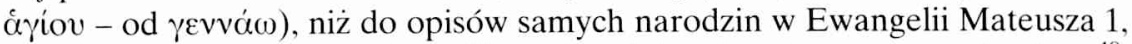

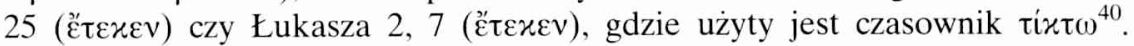
Wynika z tego, iż do najstarszych reguł wiary włączano raczej ewangeliczne słowa anioła, zapowiadające narodziny Chrystusa, nie zaś teksty narracyjne opisujące Jego narodzenie. W ten sposób również reguła wiary stawała się w pewnym sensie tekstem „objawionym” bezpośrednio przez Boga. Pójdźmy jednak głębiej w tych analizach. Ściśle mówiąc, anioł zapowiadający narodzenie Jezusa używa obydwu czasowników. W Mt 1, $20 \gamma \varepsilon v v \eta \theta \dot{\varepsilon} v$, gdy zapowiada Jego

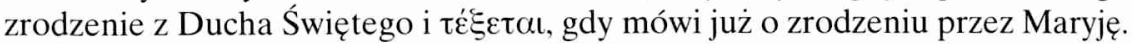
Pierwszy termin wyrażałby więc raczej poczęcie, drugi zaś zrodzenie (dosł. noszenie w sobie). Natomiast zapowiedź anioła skierowana do Maryi w Łk 1,

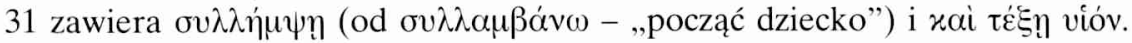
W tekście Arystydesa nasz zwrot powinien więc być przetłumaczony w sposób następujący: ,z Dziewicy Świętej został poczęty”. Reguła wiary wyraża więc w tym momencie poczęcie z Ducha Świętego, nie zaś dziewicze zrodzenie Jezusa. Taką interpretację tekstu Arystydesa zdaje się sugerować kontekst następnych sformułowań wyjaśniających właśnie dziewicze poczęcie Jezusa Chrystusa. Warto także dodać, że terminologia obecna w Apologii Arystydesa ( $\gamma \varepsilon v v \varepsilon \theta \varepsilon i \varsigma)$ nawiązuje wyraźnie do Ewangelii Mateusza, gdyż tylko tam występuje termin $\gamma \varepsilon v v \eta \theta \dot{\varepsilon} v($ Mt 1, 20). Cóż z tego może wynikać? Być może to, iż reguła wiary, którą przytacza Arystydes powstała w środowisku chrześcijan, w którym Ewangelia Mateusza cieszyła się największym powodzeniem. Chociaż trudno jednak byłoby precyzyjniej określić to środowisko, to można przypuszczać, że było to środowisko chrześcijan palestyńskich lub syryjskich.

Dziewicze poczęcie Jezusa Chrystusa jest podkreślone wyraźnie przez dwa

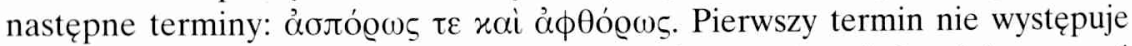
w Nowym Testamencie, natomiast w grece klasycznej posiada wiele znaczeń jak: „nie zasiany”, „rosnący bez uprawy”, „zrodzony bez zapłodnienia”41.

${ }^{39}$ Por. Epistula ad Trallianos 9,1, SCh 10,118, BOK 10, 126: „Bądźcie więc głusi, kiedy mówią wam o czymś innym, niż o Jezusie Chrystusie z rodu Dawida, Synu Maryi ( tỗ éx Ma@ias)...". Rendel Harris w swojej rekonstrukcji tekstu proponuje dołączyć imię Maryi, tak iż cały artykuł brzmiałby: „I w Jezusa Chrystusa zrodzonego z dziewicy Maryi” (s. 25). Z kolei Alpigiano, raczej słusznie, woli rekonstrukcję tekstu greckiego „narodził się z dziewicy”. Nie ma żadnych podstaw, by dodawać imię Maryi w tekście.

${ }^{40}$ Por. R. Popowski, Wieki Stownik Grecko-Polski Nowego Testamentu, Warszawa 1997, s. $106,603$.

${ }^{41}$ Por. H. G. Liddell - R. Scott, A Greek-English Lexicon, Oxford 1994, 260. 
W naszym kontekście oznacza poczęcie Chrystusa w sposób inny od zwykłych ludzi, tzn. bez udziału nasienia męskiego. Termin ten niejako dopełnia wcześniejsze stwierdzenia dotyczące wcielenia Chrystusa: „poczęty za sprawą Ducha Świętego”, „zrodzony z Dziewicy” bez udziału mężczyzny. Drugi termin, również nie występujący w takiej formie w Nowym Testamencie, oznacza „nieskazitelny”, ,czysty”, i w odniesieniu do Chrystusa opisuje Jego wolność od wszelkiego skażenia tym wszystkim złym, co niesie ze sobą natura ludzka. Można oczywiście pytać dalej: co oznacza owa nieskazitelność Chrystusa dla Arystydesa, ale w samym tekście Apologii niewiele znajdziemy na ten temat. Ten artykuł wiary oznaczał dla chrześcijan II wieku, iż Chrystus poczęty w inny sposób niż zwykli ludzie, wolny jest od skazitelności przekazywanej poprzez ludzkie poczęcie. Widać tutaj wyraźne nawiązanie do teologii Pawłowej o Chrystusie, podobnym do nas we wszystkim oprócz grzechu. Tę myśl wyraża

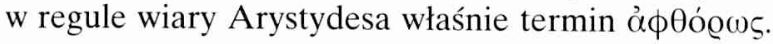

Kolejny zwrot podkreśla bardzo zdecydowanie realizm wcielenia: $\sigma \alpha ́ \varrho x \alpha$ $\hat{\alpha} v \dot{\lambda} \lambda \alpha \beta \varepsilon$. Kontekst formowania się tej najstarszej reguły wiary był niewątpliwie

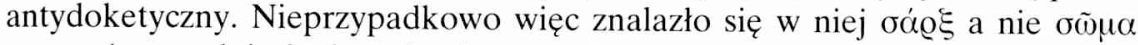
z wyraźnym odniesieniem do słynnego Prologu z Ewangelii Janowej. Warto jednak pamiętać, że samo oá@§ posiada wiele znaczeń: ciało, czyli dosłownie to, co pokrywa kości, ale także ciało jako substancja materialna, ciało w sensie „człowiek”, natura ludzka, ciało jako cielesność i doczesność, czy wreszcie ciało jako synonim zła i słabości. Wszystkie te znaczenia w jakimś sensie mieszczą się w naszym tekście, który podkreśla rzeczywiste, a nie pozorne przyjęcie przez Chrystusa natury ludzkiej. Cały zwrot $\sigma \alpha \dot{\alpha} \alpha \alpha \alpha \dot{\alpha} v \dot{\lambda} \lambda \alpha \beta \varepsilon$ wyraża, że Chrystus, choć stał się człowiekiem, jak wyjaśnia sam tekst nieco dalej, by wypełnić wspaniały plan Bożej ekonomii zbawienia ( $x \alpha \tau^{\prime}$ oixovouiav $\mu \varepsilon \gamma \alpha \dot{\lambda} \lambda \eta$ ), sam przyjął ciało ludzkie $\mathrm{z}$ własnej woli w odpowiedzi na Boży plan zbawienia. Schemat chrystologiczny, jakim posługuje się reguła wiary przytoczona przez Arystydesa, jest typowym schematem Logos-sarx. Nie znajdujemy w tekście Apologii żadnego fragmentu, który prezentowałby w takiej bądź innej formie naukę o wcieleniu (albo nawet poza nią) w schemacie chrystologii Logosanthropos. Schemat Logos-sarx pozwalał z jednej strony uwypuklić niewątpliwie bardziej realizm wcielenia przeciwko tendencjom doketycznym, z drugiej zaś, ze względu na czasową odległość apolinaryzmu, był wystarczająco bezpieczny i wystarczał w zupełności do wyrażenia wiary w przyjęcie przez Syna Bożego ludzkiej natury.

I wreszcie ostatni interesujący nas artykuł reguły przytaczanej przez Arys-

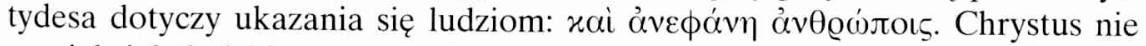
przyjął ciała ludzkiego po to, aby pozostać w ukryciu, lecz dlatego, iż przyszedł spełnić bardzo konkretną misję właśnie wobec ludzi. Zwrot oznacza jako takie ukazanie się Chrystusa ludziom w ludzkim ciele, ale również odnosi się do publicznej działalności Jezusa, Jego słów i czynów. Nie przyjął On ciała, które 
byłoby niewidzialne dla innych, lecz prawdziwe ludzkie ciało, postrzegane jako takie przez ludzi. Zwrot ten wzmacnia wyraźnie wyznanie wiary w realizm wcielenia. Syn Boży naprawdę przyjął ciało ludzkie, ponieważ w ten sposób ukazał się ludziom. Dalej, poprzez słowa i czyny dokonane w ciele ludzkim ukazał On ludziom swoją prawdziwą boską naturę. Ukazanie się ludziom w ciele było więc zarówno epifanią prawdziwie przyjętej natury ludzkiej Jezusa, jak również epifanią boskiej natury Syna Bożego.

Tekst reguły wiary w Apologii Arystydesa wzbudził oczywiście wiele dyskusji i kontrowersji. Niektórzy badacze, jak np. O'Ceallaigh, negują możliwość istnienia już w II wieku symbolu wiary z tak rozbudowanym komma chrysto$\operatorname{logicznym}^{42}$. Wiemy jednak, że bardzo podobna forma symbolu była używana w Kościele Rzymskim już w połowie II wieku, jak to potwierdza I Apologia św. Justyna $^{43}$ lub pod koniec II wieku (ok. 200 r.), jak o tym świadczy Traditio Apostolica św. Hipolita ${ }^{44}$. Co więcej, podobne elementy znajdujemy już w Listach św. Pawła (Rz 1, 3-4; Ef 1, 20; Kol 1, 15-20; Flp 2, 5-11). Tak więc nic nie wskazuje na to, aby tego typu symbol nie mógł istnieć już w 1. poł. II wieku. Zresztą, jak widzieliśmy wyżej, reguła wiary przytaczana przez Arystydesa nie jest typową formułą syntezy z rozbudowanym komma chrystologicznym, jakie znamy z innych tekstów II wieku. Po drugie, O’Ceallaigh sądzi, że

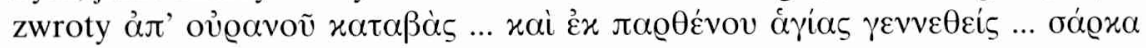
${ }_{\alpha} v \varepsilon \dot{\lambda} \alpha \beta \varepsilon$, nie pojawiają się nigdy razem w zachodnich symbolach wiary. Jego zdaniem, obecność tych elementów w Apologii Arystydesa oznacza, iż mamy tutaj ślad jakiegoś późniejszego symbolu wschodniego. Potwierdziłaby to także wzmianka o Duchu Świętym i „ekonomii” Bożej, które, jego zdaniem, pojawiają się po raz pierwszy w chrzcielnym symbolu konstantynopolitańskim z 360 roku. W konsekwencji więc przytaczana reguła wiary, a może nawet cała Apologia, zostałaby ostatecznie zredagowana dopiero w IV wieku. Słusznie jednak zauważa Alpigiano, że sugestia O'Ceallaigha jest pozbawiona pod-

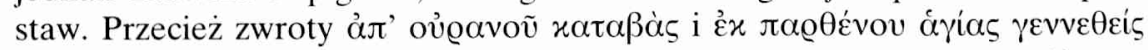
pojawiają się już w Nowym Testamencie (J 3, 13; 6, 33.38.41; Ef 4, 9-10) oraz

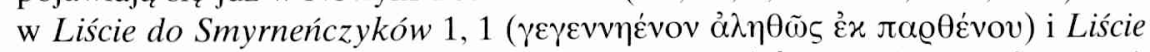

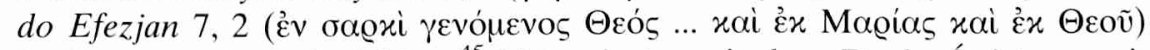
św. Ignacego Antiocheńskiego ${ }^{45}$. Natomiast wzmianka o Duchu Świętym znajduje się już w Łk 1, 35, a potem w Traditio Apostolica św. Hipolita oraz w Epistula Apostolorum ${ }^{46}$. Wreszcie termin „ekonomia” jest potwierdzony również przez Ignacego Antiocheńskiego. Obecność tych elementów w naszej

${ }^{42}$ Por. G.C. O'Ceallaigh, <Marcianus $>$ Aristides, on the worship of God, HTR 51 (1958) 227-254.

${ }_{43}$ Por. Apologia I 61, PG 6, 420-421, POK 6,71.

${ }^{44}$ Por. Traditio Apostolica 21, SCh 11bis, 85-87.

45 Por. Epistula ad Smyrnenses 1,1; Epistula ad Ephesios 7,2, SCh 10, 154, 74.

${ }^{46}$ Por. Traditio Apostolica 21, SCh 11bis, 86; Epistula Apostolorum 3. 
Apologii niekoniecznie więc oznacza, iż są one dodatkami z IV wieku ${ }^{47}$. Wszystko natomiast wskazuje, że mamy przed sobą rzeczywistą regułę wiary z II wieku.

\section{TEOLOGIA WCIELENIA W PISMACH JUSTYNA MĘCZENNIKA}

Justyn jest drugim autorem chrześcijańskim II wieku, który zajmuje się tematyką wcielenia. ${ }^{48}$ Choć, podobnie jak Arystydes, nie czyni on z naszej tematyki elementu centralnego swojej ekspozycji, to jednak rekonstrukcja jego teologii wcielenia jest zdecydowanie trudniejsza. O ile bowiem w Apologii Arystydesa tematyka ta została przedstawiona praktycznie tylko w jednym konkretnym tekście reguły wiary, o tyle w przypadku Justyna jest ona rozproszona po jego pismach. Stąd też również większa trudność jej syntetycznego przedstawienia. Truizmem będzie przypomnienie, że zajmę się tutaj oczywiście analizą tylko autentycznych pism Justyna, a więc 1 i 2 Apologiq oraz Dialogiem z Żydem Tryfonem. ${ }^{49}$ Pomijając tekst I Apologii 32, 2, w którym autor przedstawia chrystologiczną interpretację proroctwa dotyczącego przyszłego władcy Judy ( $\operatorname{Rdz} 49,10)$ i mówi ogólnie o zjawieniu się Chrystusa wśród ludzi, refleksję Justyna nad tajemnicą wcielenia można zgrupować wokół trzech zagadnień: „stał się człowiekiem”, „wcielił się” oraz „począł i narodził się z Dziewicy".

1. Stał się człowiekiem. W pierwszej grupie tekstów, rozrzuconych oczywiście po wszystkich pismach, Justyn stwierdza wyraźnie, iż istotą tajemnicy wcielenia był fakt stania się Logosu człowiekiem. Czyni to nasz autor za pomocą różnych sformułowań, które teraz syntetycznie przedstawimy. Pierwszą odnajdujemy już w następującym zdaniu:

\footnotetext{
s. 26-27.

${ }^{48} \mathrm{Na}$ temat Justyna i jego teologii - zob. A. Lisiecki, Wstęp, w: Justyn Męczennik, Apologia. Dialog z Żydem Tryfonem, tłum. ks. A. Lisiecki, POK 4, Poznań 1926, s. XI-CXV; L. M. Bernard, Justin Martyr. His Life and Thought, Cambridge 1967; E. R. Goodenough, The Theology of Justin Martyr. An Investigation into the Concepts of Early Christian Literature and Its Hellenistic and Judaistic Influences, (reprint) Amsterdam 1968; E. Osborn, Justin Martyr, Tübingen 1973; W. A. Shotwell, The Biblical Exegesis of Justin Martyr, London 1965; O. Skarsaune, The Proof from Prophecy, Leiden 1987; P. Merlo, Liberi per vivere secondo il Logos. Principi e criteri dell'agire morale in San Giustino filosofo e martire, Roma 1994; G. Girgenti, Giustino Martire. Il primo cristano platonico, Milano 1995.

49 Pomijam tutaj Martyrium S. Iustynii et sociorum, ponieważ Justyn podczas procesu mówi tylko ogólnie o przyjściu do ludzi zapowiadanego przez proroków Mesjasza.
}

${ }^{47}$ Por. Epistula ad Ephesios 18,2 i 20,1, SCh 10, 86 i 90; zob. Alpigiano, Introduzione, dz. cyt. 
„Nie tylko bowiem wśród Greków przez Sokratesa Logos potwierdził tę prawdę, ale także wśród barbarzyńców ten sam Logos, który przyjął widzialną postać, stał się czlowiekiem i nazywany jest Jezusem Chrystusem". 50

Fragment ten pojawia się w kontekście prezentacji teorii o złych demonach, które ludzie nazwali bogami, i gdy potem Sokrates próbował przekonać ich o fałszywości takich przekonań, demony wydały go na śmierć. Justyn przedstawia Logos jako nauczyciela prawd o złych demonach Grekom za pośrednictwem filozofii Sokratesa, podkreśla natomiast, iz barbarzyńcom, uczynił to osobiście, przyjmując widzialną postać i stając się człowiekiem. Warto zauważyć, że Justyn widzi wcielenie w kontekście objawiania prawdy barbarzyńcom, a nie Grekom. Schemat prezentacji jest wyraźnie wstępujący: $\mu$ oф $\omega \theta \dot{\varepsilon} v \tau o \varsigma$ -

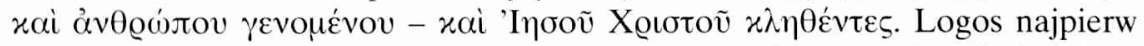
przybiera widzialną postać, choć niestety Justyn nie wyjaśnia bliżej, jak to rozumie, potem przyjmuje formę człowieka i wreszcie zostaje nazwany Jezusem Chrystusem. Justyn, jak to zobaczymy również dalej, posiada talent do tworzenia chrześcijańskich neologizmów na opis tajemnicy wcielenia. Jest pierwszym autorem chrześcijańskim, który używa czasownika $\mu$ sanie przyjmowania widzialnej postaci przez Logos. ${ }^{51}$ Również drugi zwrot jest bardzo ciekawy. Podczas gdy w Prologu Ewangelii Janowej znajdujemy okreś-

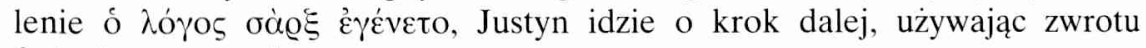

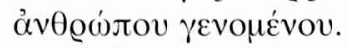

W innym miejscu Apologii Justyn identyfikuje Logos z rzeczywiście zrodzonym Synem Bożym, który stał się człowiekiem:

„Sam Jezus Chrystus został zrodzony jako Syn Boży, będąc Logosem, Pierworodnym i Mocą, według Jego (tj. Boga) stawszy się człowiekiem ( $\gamma \varepsilon v o ́ m \varepsilon v o s$

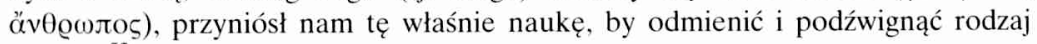
ludzki". ${ }^{52}$

W wyżej cytowanym tekście nasz apologeta podaje również motywację soteriologiczną wcielenia „by odmienić i podźwignąć rodzaj ludzki”. Jest ona jeszcze bardziej widoczna w innej wypowiedzi:

${ }^{50}$ Apologia I 5,4, PG 6, 336B lub wyd. E. J. Goodspeed, Die ältesten Apologeten, Göttingen

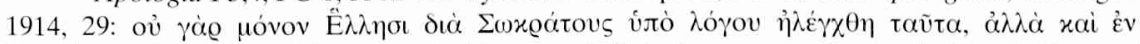

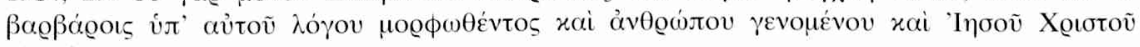

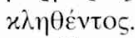

${ }^{51}$ Justyn jako jedyny z Apologetów używa tego czasownika - por. E. Goodspeed, Index Apologeticus, Leipzig 1912, 180. Pojawia się on również, co prawda, w pismach Ojców Apostolskich, lecz poza kontekstem nauki o wcieleniu - zob. E. Goodspeed, Index Patristicus sive Clavis Patrum Apostolicorum operum, Peabody 1993, 146.

52 Apologia I 23,2, PG 6, 364 AB, Goodspeed s. 42, thum. A. Lisiecki, POK 4, 29. 
„O tym, że dla nas stał się człowiekiem, zechciał cierpieć i być znieważanym oraz że powtórnie powróci w chwale, posłuchajcie mówiących o tym proroctw". ${ }^{53}$

W tym tekście mowa jest nie tylko ogólnie o ukazaniu się Logosu w naturze ludzkiej w celu przekazania ludziom nauki o zbawieniu, ale jest też wyraźne wyakcentowanie formy, w jakiej dokonało się odkupienie: poprzez stanie się

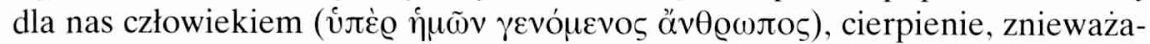
nie i powtórne przyjście na ziemię. Justyn przedstawia swoją naukę o wcieleniu Syna Bożego i Logosu nie tylko w I Apologii skierowanej, jak wiemy, do cesarza, ale również w Dialogu z Żydem Tryfonem potwierdza ją wielokrotnie, właśnie w kontekście kontrowersji z judaizmem. Oznacza to, iż nauka ta była już dosyć mocno zakorzeniona w świadomości chrześcijan II wieku i stanowiła fundament ich teologicznej tożsamości zarówno w dyskusji z poganami jak i Żydami. W tymże Dialogu znajdujemy następujące chrystologiczne wyznanie wiary Justyna:

„Uznaję bowiem, że również zgodził się na to, by umrzeć na krzyżu, stać się człowiekiem i cierpieć wszystko, co zadali mu wasi rodacy". ${ }^{54}$

W kontekście polemicznym, zarzucając niektórym Żydom odpowiedzialność za cierpienia zadawane Chrystusowi, Justyn podkreśla realizm Jego cierpień, a więc także Jego człowieczeństwa. W innym miejscu Dialogu ta sama tematyka powraca w retorycznym pytaniu: „Czy myślicie, że według Pism należy czcić i nazywać Panem Bogiem kogoś innego oprócz Stwórcy wszechś-

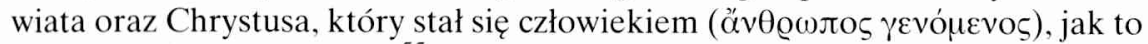
wam tyle Pism wykazało?"

Jak już pisałem wyżej, Justyn do wyrażenia tajemnicy Logosu, Syna Bożego, Pierworodnego, Mocy, Chrystusa stającego się człowiekiem używa prak-

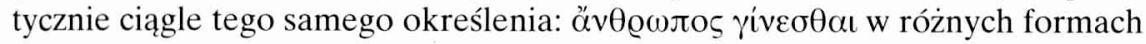
gramatycznych. Drobny wyjątek stanowi tutaj jedynie wypowiedź w II Apologii, gdzie nasz apologeta pisze „sam z siebie przyjął naszą naturę (ó

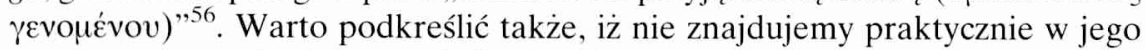

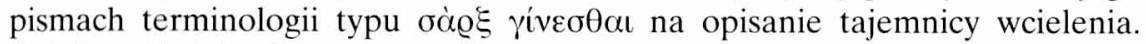
Dalej, jeśli, jak się często podkreśla, chrystologia Logos-sarx rozwijała się w kontekście antydoketycznym I i II wieku, to w przypadku Justyna, a przy-

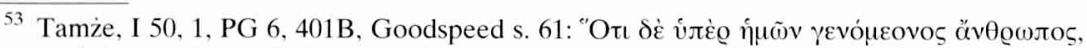

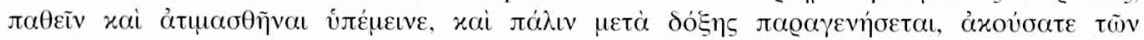

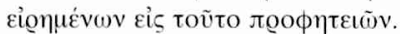

54 Dialogus cum Judaeo Tryphone 67,6, PG 6, 629 D, Goodspeed s. 175: Kai үà@ tò

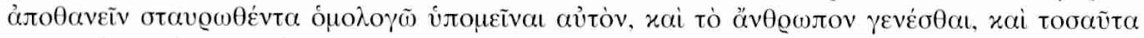

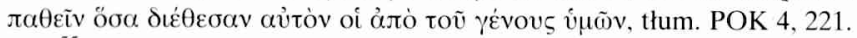

55 Tamże, 68, 3, PG 6, 633 B, thum. POK 4, 223.

56 Apologia II 10, 8, PG 6, 461 A. 
pomnijmy, że jesteśmy nadal w połowie II wieku, mamy wyraźnie do czynienia

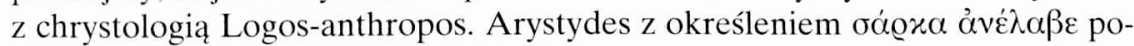
zostawał jeszcze w obrębie schematu Logos-sarx, natomiast Justyn przechodzi już bardzo zdecydowanie do prezentacji Logos-anthropos. Warto chyba zapytać w tym momencie o motywy takiej właśnie prezentacji. Przecież dzieliło ich zaledwie kilkadziesiąt lat. Dlaczego Justyn nie używa wcale schematu Logossarx do opisu wcielenia, ale zawsze schemat Logos-anthropos? Znika zagrożenie doketystyczne, Justyn był rzeczywiście teologiem zdecydowanie większego formatu stosując (czy wręcz wymyślając) jako pierwszy schemat Logos-anthropos, czy też obydwa schematy, to po prostu wymysł badaczy współczesnych? Bardzo trudno jest odpowiedzieć jednoznacznie na te pytania. Myślę, że w pewnym sensie zaważyły tu wszystkie trzy czynniki. Na pewno w Rzymie wpływy doketów były mniejsze niż na Wschodzie chrześcijaństwa. Nie ulega również wątpliwości, że Justyn to pierwszy wielki teolog chrześcijański. Po trzecie wreszcie, teksty Justyna pokazują jak zwodnicze bywa myślenie schematami. Utarło się przekonanie, iż schemat Logos-anthropos pojawia się w okresie kontrowersji z apolinaryzmem w IV wieku, kiedy to schemat Logos-sarx okazuje się niewystarczającym. Nic bardziej mylnego. Schemat Logosanthropos wymyślił Justyn dwa wieki wcześniej, jako terminologię służącą do pozytywnej (a nie tylko apologetycznej) teologicznej prezentacji tajemnicy wcielenia zarówno poganom jak i Żydom. Schematy bywają oczywiście użyteczne gdy porządkują myślenie, ale musimy ciągle pamiętać, iż prawie zawsze są pewnym uproszczeniem.

2. Wcielił się. W drugiej grupie tekstów Justyn opisuje tajemnicę wcielenia

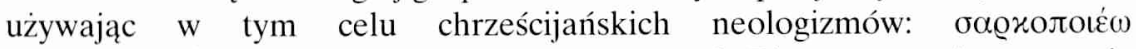
i $\sigma \omega \mu \alpha \tau$ толоє்́ $\omega$ różnych formach gramatycznych. Pierwszy termin występuje wcześniej tylko raz w tekstach Plutarcha, ${ }^{57}$ nie pojawia się natomiast w tekstach Nowego Testamentu, ani w pismach Ojców Apostolskich czy też Apologetów greckich II wieku. ${ }^{58}$ Drugi natomiast czasownik, licznie potwierdzony przez literaturę klasyczną, gdzie przyjmuje różne znaczenia (,istnienie cielesne”, „przedstawienie w sztuce”, ,personifikacja”), ${ }^{59}$ również nie występuje we wcześniejszych pismach chrześcijańskich. Justyn jest pierwszym autorem chrześcijańskim, który używa tych terminów w refleksji nad wcieleniem Syna Bożego, dostosowując oczywiście ich klasyczne znaczenie do wymogów teologii chrześcijańskiej. Dodajmy wreszcie, że owe neologizmy chrześcijańskie zastosowane po raz pierwszy przez naszego autora, stały się w późniejszym

57 Por. H. G. Liddell - R. Scott, A Greek-English Lexicon, Oxford 1994, s. 1584.

58 Por. E. Goodspeed, Index Apologeticus, Leipzig 1912; tenże, Index patristicus sive Clavis Patrum Apostolicorum operum, Peabody 1993.

${ }^{59}$ Por. H. G. Liddell - R. Scott, A Greek-English Lexicon, s. 1749. 
okresie swego rodzaju terminami technicznymi w teologii wcielenia. Pierwszym miejscem, w którym pojawia się nasza tematyka jest I Apologia:

„Pierwszą Mocą po Bogu, Ojcu i Panu wszystkiego a także Jego Synem jest właśnie Logos. Później powiemy, w jaki sposób On się wcielił i stał się człowiekiem". 60

Przytoczony fragment wpisuje się w szerszy kontekst tekstu, w którym Justyn rozwija argumentację za boskim pochodzeniem Chrystusa podkreślając jednocześnie Jego stanie się człowiekiem. Apologeta podkreśla więc wyraźnie zarówno prawdziwe bóstwo jak i prawdziwe człowieczeństwo Chrystusa. Nie miałoby bowiem najmniejszego sensu pisanie o wcieleniu, gdyby nie chodziło o przyjęcie natury ludzkiej przez Syna Bożego. Warto również dodać, iż Justyn w tym samym tekście zaraz precyzuje za pomocą drugiego zwrotu, że wcielenie nie oznacza wcale jakiejś enigmatycznej, blizej nie sprecyzowanej rzeczywistości, ale właśnie fakt ,,stania się człowiekiem”. W innym miejscu tejże Apologii Justyn opisując chrześcijańską Eucharystię, zaznacza wyraźnie, iż mogą uczestniczyć w niej tylko ci, którzy są ochrzczeni, wierzą w naukę Chrystusa i żyją tak, jak On polecił. Eucharystia jest bowiem ciałem i krwią właśnie Jezusa wcielonego:

„Jak za sprawą Słowa Bożego wcielony Jezus Chrystus nasz Zbawiciel przyjął ciało i krew dla naszego zbawienia, tak samo ten pokarm, co stał się Eucharystią dzięki Jego własnemu słowu, karmi przez przemienienie nasze ciało i krew. Pokarm ten, jak zostaliśmy pouczeni, jest ciałem i krwią tego właśnie wcielonego Jezusa."61

Również w tym tekście Justyn podkreśla soteriologiczną celowość wcielenia

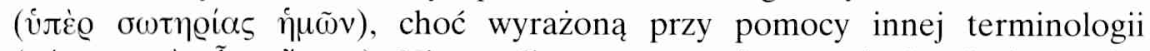

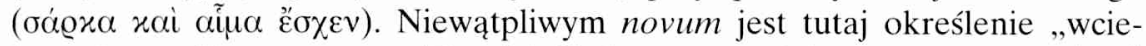

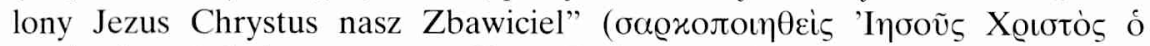

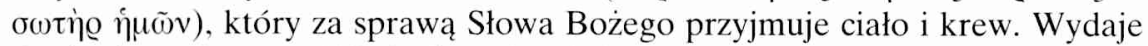
się, że druga jego część jedynie wyjaśnia i precyzuje pierwszą, gdyż w przeciwnym wypadku twierdzenie, ze wcielony Jezus przyjmuje ciało i krew, byłoby swego rodzaju tautologią. Justyn eksplikuje, że wcielenie oznacza właśnie przyjęcie ciała i krwi ludzkiej. W każdym razie, zarówno ten fragment tekstu, jak również dalszy określający Eucharystię ciałem i krwią wcielonego

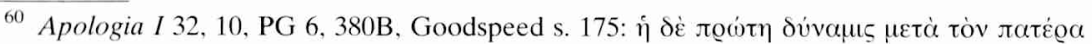

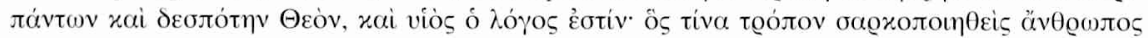

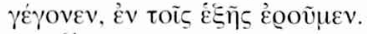

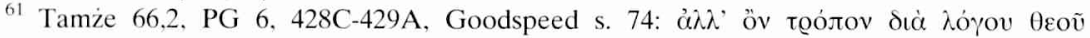

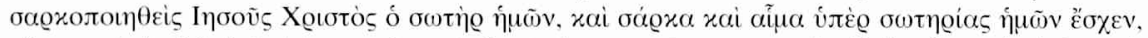

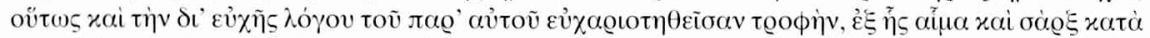

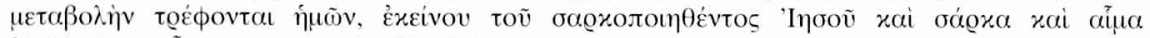

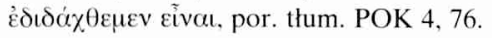




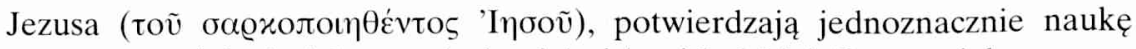
Justyna o wcieleniu jako przyjęciu ciała i krwi ludzkiej. Pewną ciekawą specyfiką tego fragmentu jest próba pokazania przez Justyna analogii pomiędzy wydarzeniem wcielenia, a przemianą eucharystyczną. ${ }^{62}$

Także w Dialogu, gdzie Justyn przyznaje, iz ci, którzy w czasach przed przyjściem Chrystusa postępowali zgodnie z Prawem Mojżeszowym czyniąc wszystko, co z natury jest zawsze dobre dostąpią zbawienia na równi „z tymi co uznają, że Chrystus jest Synem Bożym, który istniał przed jutrzenką i księżycem, narodził się $\mathrm{z}$ Dziewicy $\mathrm{z}$ rodu Dawida, stając się wcielonym

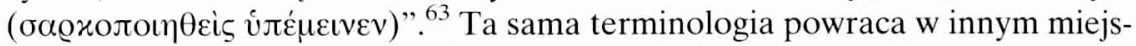
cu Dialogu, gdzie Justyn odnosi proroctwo Iz 7, 14 do osoby Chrystusa, widząc właśnie w Jego zrodzeniu z dziewicy i przyjęciu ciała ludzkiego znak zapowiadany przez Izajasza:

„Rzeczywiście prawdziwym i mającym się stać godnym wiary dla rodzaju ludzkiego znakiem jest właśnie to, że z dziewiczego łona pierworodny wszelkich stworzeń wcielił się i naprawdę jako dziecko się narodzil." ${ }^{64}$

Dla Justyna jest sprawą oczywistą, iż tekst proroctwa odnosić się może tylko do Chrystusa. Gdyby bowiem narodził się tak jak inni ludzie, tzn. z połączenia cielesnego, prorocka zapowiedź Jego narodzenia właśnie jako znaku nie miałaby żadnego sensu. Dwoistość ,natury” Chrystusa, z jednej strony jako Syna Bożego preegzystującego, z drugiej zaś jednocześnie potomka Patriarchów, który przyjął ciało $\mathrm{z}$ dziewicy stając się człowiekiem podległym cierpieniom, stwierdza nasz Apologeta w Dialogu:

„Objawił więc nam wszystko to, co dzięki Jego łasce pojęliśmy z Pism, czyli, że wiemy, iż jest On pierworodnym Boga istniejącym przed wszelkimi stworzeniami, jest także Synem Patriarchów ponieważ przez dziewicę z ich rodu wcielił się i stał się człowiekiem bez piękna i nieszacownym oraz podległym cierpieniom". ${ }^{5}$

62 Szerzej na ten temat wraz z bibliografią zob. J. Słomka, Pokarm i Ofiara, Łódź 2000, 46-50.

63 Dialogus cum Judaeo Tryphone 45,4, PG 6, 572C-573A, tłum. Lisiecki, POK 4, 173. Tłu-

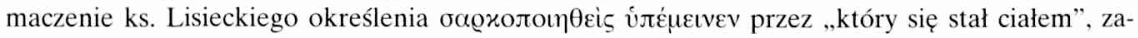

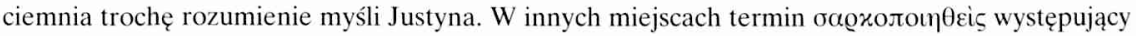
w pismach Justyna był zazwyczaj tłumaczony właśnie przez ,, wcielenie”. W Dial. 45,4 mamy więc również do czynienia z neologizmem Justyna, a nie ze zwyczajną terminologią biblijną „stał się ciałem".

${ }^{64}$ Tamże, 84,2, PG 6, 673B, Goodspeed s. 196: $\alpha \lambda \lambda$ ' ö

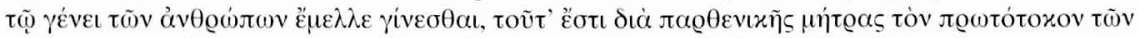

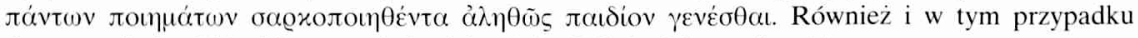
thumaczenie ks. Lisieckiego „stał się ciałem” (s. 253) budzi wątpliwości.

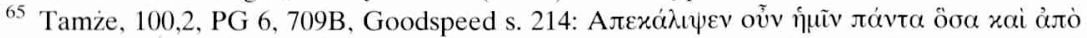

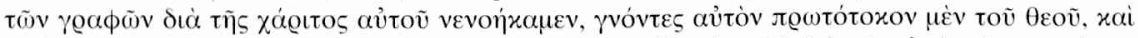

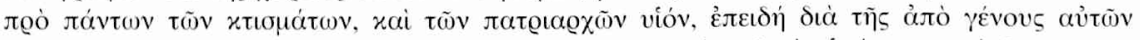

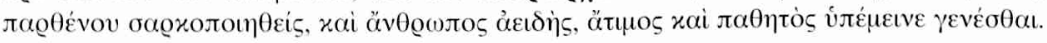


Dialog, jak wiemy, jest zapisem dyskusji Justyna z przedstawicielami judaizmu, z oczywistych więc względów przeważa w nim argumentacja za bóstwem i preegystencją Mesjasza w oparciu o teksty Starego Testamentu. Fakt, że Jezus jest prawdziwym człowiekiem, nie budził większych kontrowersji również w środowisku żydowskim. Przyjmowali bowiem chętnie, iż jest On człowiekiem, jak każdy inny człowiek. Nie miało to jednak nic wspólnego z chrześcijańskim rozumieniem wcielenia, które musiało być oparte na nauce i wierze w bóstwo Chrystusa. Nie przypadkowo właśnie w tekstach Dialogu Justyn ciągle wpisuje teologię wcielenia w argumentację o preegzystencji i boskim pochodzeniu Syna Bożego.

Drugim terminem, którego używał Justyn na opisanie tajemnicy wcielenia jest już wspomniany wcześniej $\sigma \omega \mu \alpha \tau о \pi о \varepsilon \dot{\omega} \omega$. W analizowanym Dialogu znajdujemy argumentację Apologety z Flavia Neapolis przeciwko kultowi Mitry oraz uzasadnienie boskiego pochodzenia Mesjasza według proroctwa Dn 2, 34 . W takim właśnie kontekście przytacza Justyn także proroctwo Iz 33, 13-19, odnosząc je do Eucharystii jako pamiątki wcielenia Chrystusa:

„Oczywistym jest, że w tym proroctwie mowa jest również o chlebie, którego sprawowanie przekazał nam nasz Chrystus na pamiątkę swego wcielenia dla tych, którzy w Niego wierzą, a dla których poddał się także cierpieniom." 66

Dwa elementy zasługują na podkreślenie w tym tekście. A więc po pierwsze, Justyn rozumie Eucharystię jako pamiątkę wcielenia i męki Chrystusa, co jest niewątpliwie myślą nową i oryginalną. ${ }^{67}$ Drugim bardzo ważnym elemen-

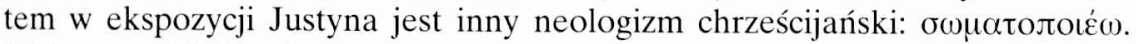
Niełatwo udzielić odpowiedzi na pytanie, dlaczego Justyn używał zawsze określenia ба@холоє́́ $\omega$ na oznaczenie wcielenia, a jedynie tylko ten jeden raz za-

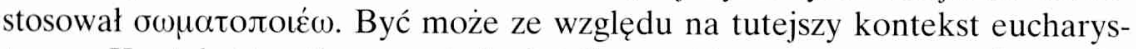
tyczny. Kontekst ten thumaczy jednak tylko częściowo jego motywację, ponieważ również w cytowanej I Apologii $(66,2)$ właśnie kontekst jest eucharystycz-

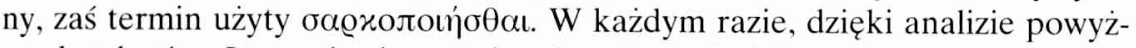
szych tekstów, Justyn jawi nam się zdecydowanie jako twórca neologizmów

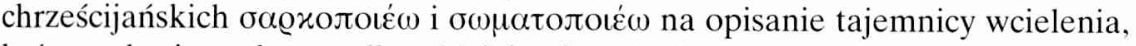
które stały się podstawą dla późniejszej tradycji kościelnej. Okazuje się, iż był on nie tylko, jak się powszechnie podkreśla, filozofem chrześcijańskim, lecz także bardzo twórczym teologiem, który od rozważań kosmologicznych czy antropologicznych potrafił łatwo przechodzić na obszar wyjaśniania prawd wiary chrześcijańskiej wykorzystując i adoptując zdobycze kultury helleńskiej.

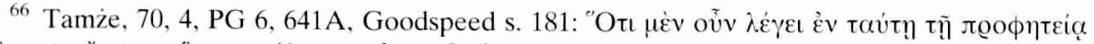

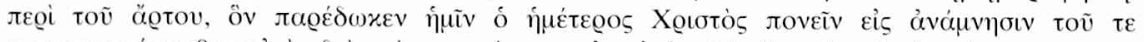

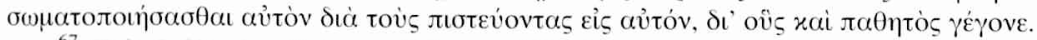

${ }^{67}$ Zob. J. Słomka, Pokarm i Ofiara, s. 165-167. 
3. Poczęcie i narodzenie z Dziewicy. Trzecim elementem Justynowej teologii wcielenia jest nauka o dziewiczym poczęciu i zrodzeniu Chrystusa. Jest to jednocześnie obszar najmniej oryginalny w jego refleksji, gdyż właściwie potwierdza w nim wszystko to, co znamy z tekstów Ewangelii Mateusza i Łukasza. Teksty, a ściślej mówiąc pojedyncze i lapidarne stwierdzenia są rozproszone po wszystkich pismach Justyna. Tutaj przedstawię jedynie najważniejsze fragmenty. ${ }^{68}$ A więc najpierw w I Apologii Justyn przytaczając zasadnicze elementy wyznania wiary z jego czasów stwierdza:

„Prawda, mówimy jeszcze, że Słowo, pierworodna Boża Latorośl, Jezus Chrystus, nasz Nauczyciel, bez złączenia cielesnego został zrodzony, że wisiał na krzyżu, umarł, zmartwychwstał i wstąpił do nieba." ${ }^{69}$

Kontekst tej wypowiedzi potwierdza wyraźnie, iż nauka o dziewiczym poczęciu Chrystusa była już w połowie II wieku jednym z zasadniczych elementów reguły wiary. Jednocześnie Justyn odcina się bardzo zdecydowanie od pojmowania zrodzenia Jezusa Mesjasza w sposób mitologiczny choć przyznaje, iż język mitologii może być użyteczny do zrozumienia tej tajemnicy. W innym miejscu Justyn wyjaśnia szerzej tę tematykę. Dziewicze poczęcie Mesjasza dzięki nadzwyczajnej interwencji Boga, nie może być rozumiane w sposób taki, jak to wyjaśniali poeci, że „Zeus dla zaspokojenia swoich pożądliwości do niewiast się zblizał":
„A zatem wyrażenie «Oto Dziewica będzie brzemienna» znaczy, że Dziewica pocznie, z nikim się nie łącząc; gdyby się bowiem z kimkolwiek złączyła, jużby więcej nie była dziewicą. Oto Moc Boża zstąpiła na Dziewicę, cieniem ją swoim okryła i uczyniła brzemienną, nie naruszając jej dziewictwa."

W wielu innych fragmentach pism Justyna znajdujemy praktycznie tylko stwierdzenia o dziewiczym narodzeniu Chrystusa bez jakiegokolwiek komentarza, a jedynie $z$ odniesieniem do proroctwa par excellance dotyczącego tej

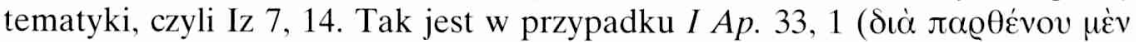
$\tau \varepsilon \chi \theta \eta \sigma o ́ \mu \varepsilon v o \varsigma)$. Natomiast w pozostałych tekstach kontekstem stwierdzeń Justyna dotyczących naszej tematyki jest wyraźnie reguła wiary lub też chęć uzasadnienia, że Chrystus pochodzi z rodu Abrahama oraz pokolenia Judy

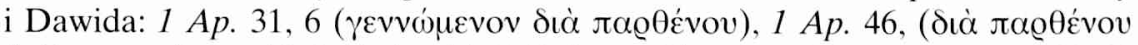

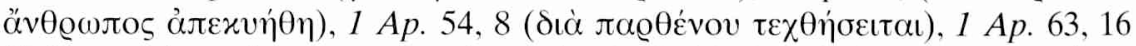

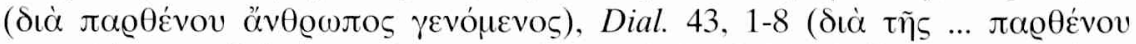

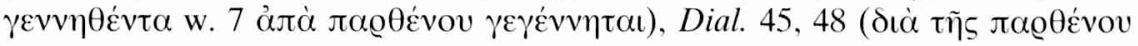

${ }^{68}$ Pomijam te fragmenty tekstów Dialogu, które są wypowiedziami Tryfona, gdyż powtarza on wywody Justyna.

69 Apologia I 21,1, PG 6, 360A, Goodspeed s. 40, POK 4, 26.

70 Tamze, 33,4, PG 6, 381A, POK 4, 39. 


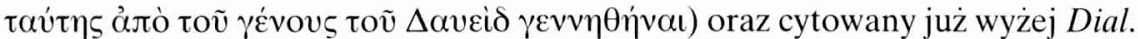

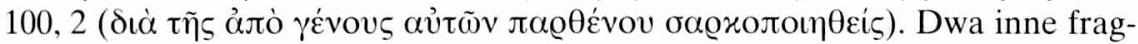
menty zasługują na to, aby je przytoczyć w całości, a mianowicie:

„Powróciłem zatem do owego miejsca swych wywodów, gdzie wyżej przerwałem dowodzenie, że Jezus narodził się z Dziewicy, i to narodzenie się Jego z Dziewicy było przepowiedziane przez Izajasza." ${ }^{71}$

W dalszej części Justyn cytuje oczywiście proroctwo Iz 7, 14. Odnajdujemy tutaj oczywiście powszechny topos argumentacji Justyna z odwołaniem się do Iz 7, 14, choć nowością jest niewątpliwie rozróżnienie pomiędzy ẻx $\pi \alpha \varrho \theta \dot{\varepsilon} v o v$ i dı̀̀ $\pi \alpha \varrho \theta \dot{\varepsilon} v o v$. Warto przypomnieć, że pierwszy zwrot pojawia się w Dialogu tylko 3 razy, natomiast drugi aż 19. Różnie są tłumaczone owe dysproporcje. G. Otranto jest przekonany, że było to spowodowane antyjudaistycznym nastawieniem Justyna. ${ }^{72}$ Powód może być jednak inny. Justyn używając dwóch formuł podkreśla jednocześnie cudowne, dziewicze zrodzenie Mesjasza, lecz także inicjatywę Boga, w której Dziewica jest tylko narzędziem ( $\delta \grave{\alpha}) .{ }^{73}$ Nasza tematyka pojawia się wraz z krótkim komentarzem również w cytowanym wcześniej Dial. 84, gdzie Justyn zaznacza, iż właśnie znakiem zapowiedzianym przez Iz 7, 14 jest fakt cudownego poczęcia i zrodzenia Chrystusa bez połączenia cielesnego. Ostatni wreszcie tekst, zasługujący na przytoczenie, pochodzi również z Dialogu, to 23, 3 w którym nasz autor identyfikuje wyraźnie Dziewicę, Matkę Jezusa Chrystusa, Syna Bożego z Maryją. Fragment ten pojawia się w kontekście argumentacji o przejściowym charakterze Prawa Mojżeszowego:

„Jeśli bowiem przed Abrahamem nie było potrzeba obrzezania, ani przed Mojzeszem szabatów, świąt i ofiar, tedy i teraz tak samo ich nie potrzeba, kiedy według woli bożej, a z Maryi, dziewicy z rodu Abrahamowego, narodził się (

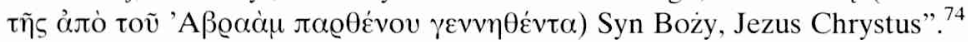

Spróbujmy przedstawić teraz syntetycznie wnioski teologiczne wyłaniające się z analizy tekstów. Otóż, nie znajdziemy jeszcze w pismach Justyna systematycznej ekspozycji nauki o wcieleniu, lecz raczej pewne pojedyncze stwierdzenia, charakterystyczne dla prekursorów, bądź też elementy wyznań wiary bez jakiegokolwiek komentarza. Warto pamiętać, iż podczas gdy jego ogólna prezentacja chrześcijaństwa opiera się na założeniach filozoficznych, to jednak

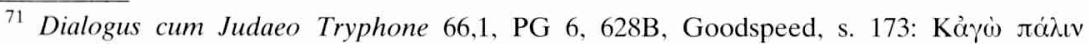

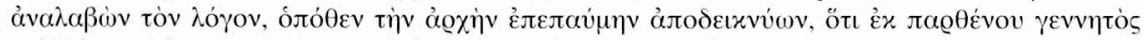

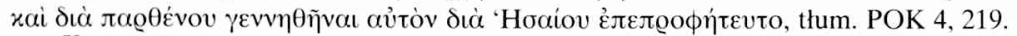

${ }_{72}$ Por. G. Otranto, Esegesi biblica e storia in Giustino, Bari 1979, 78n.

${ }^{73}$ Por. L. Misiarczyk, Il Midrash nel Dialogo con Trifone di Giustino Martire, Płock 1999, $193 n$.

74 Dialogus cum Judaeo Tryphone 23,3, PG 6, 528A, POK 4, 135. 
nauka o wcieleniu nawiązuje bardziej do tradycyjnej wiary Kościoła, obecnej w Nowym Testamencie i pismach Ojców Apostolskich. Z połączenia tych dwóch aspektów myśli rodzi się Justyna nauka o wcieleniu. ${ }^{75}$ Justyn przyjmuje jako punkt wyjścia wiarę chrześcijańską: Jezus Chrystus jest Bogiem i człowiekiem, ale do wyjaśnienia tej tajemnicy używa znanych mu narzędzi filozoficznych. Otóż według niego, Powszechny i Kosmiczny Rozum, Czysty Duch, z którym ludzie od zawsze poszukiwali kontaktu, ostatnio stał się dostępny dzięki wcieleniu się w osobę Jezusa Chrystusa. W łonie Maryi ten Posłaniec Boży stał się istotą ludzką z ciała i krwi oraz Mesjaszem żydowskim. Co ciekawe, Justyn nigdy nie mówi nic o celowości wcielenia. Być może dlatego, iż nie znajdujemy praktycznie w jego pismach nauki o grzechu pierworodnym, a te tematyki ściśle się ze sobą łączą. ${ }^{76}$

W opisie historii wcielenia Justyn idzie wyraźnie za Ewangelią Łukasza, wprowadzając jednak Ducha Świętego do zwiastowania ,oto poczniesz w łonie z Ducha Świętego" ( I Ap. 33, 6). Niesłusznie jednak badacze Justyna przywiązują do tej zmiany tak dużą wagę. Przecież jest to ostatecznie synteza tego, co

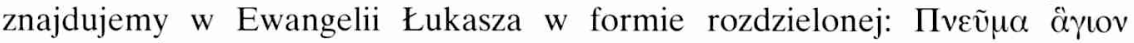

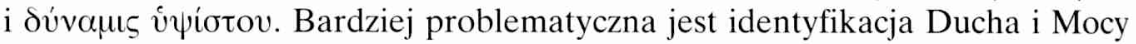
Bożej, który zstąpił na Dziewicę z Logosem i Synem Bożym (I Ap. 33, 6). Jak rozumieć to stwierdzenie? Liczne teksty potwierdzają, że Justyn określał zarówno Logos (I Ap. 23, 2; 32, 10; 60, 5; II Ap. 10, 8; Dial. 105, 1) jak Ducha

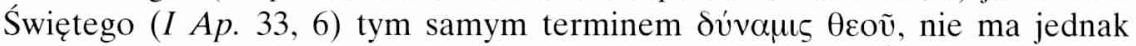
podstaw do twierdzenia, iż identyfikował osobowo Ducha Świętego z Logosem. Prawdopodobnie nie posiadał on jeszcze wystarczająco jasnych idei na temat Ducha Świętego i Jego relacji do Logosu. W niektórych tekstach ( $I$ Ap.

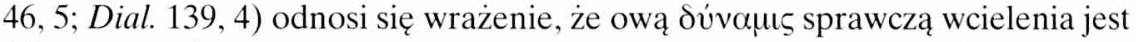

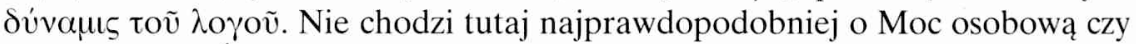
wręcz Ducha Świętego jak chcą niektórzy, ale raczej o to, że Bóg udzielił Logosowi moc stania się wcielonym i wejścia do łona Maryi. ${ }^{77}$ Justyn nie wyjaśnia dokładniej, w jaki sposób Logos działał w Maryi, odwołuje się jedynie do biblijnej terminologii „osłonienia” i proroctwa Iz 7, 14, odrzucając zdecydowanie mityczne prezentacje podobnej tematyki, gdzie przedstawiano bóstwa

${ }^{75}$ Niestety niewiele jest opracowań na temat teologii wcielenia w pismach Justyna. W j. polskim nie znalazłem żadnego, a w literaturze obcojęzycznej niewiele - por. np. J. Howton, The Theology of the Incarnation in Justin Martyr, ,Studia Patristica” (1966), s. 231-239, proponuje, by jako bazę określenia Chrystusa „Synem Bożym” widzieć aplikację tego terminu do Izraela jako narodu w judaizmie, lecz jak sam zaznacza „unfortunetely there is no clear indication” (s. 233); L. W. Barnard, Justin Martyr. His Life and Thought, Cambridge 1967, s. 117-122 streszcza zasadniczo poglądy E. R. Goodenough, The Theology of Justin Martyr, Amsterdam 1968 (reprint Jena 1923), s. 233-243, na których oparte będą również obecne analizy.

76 Dial. 100,5 jest przywołaniem tylko pewnej figury literackiej.

77 Por. E. R. Goodenough, The Theology of Justin Martyr, s. 236-237. 
w relacjach fizycznych z kobietami. Uznaje jednak jednoznacznie dziewicze poczęcie i zrodzenie Chrystusa, co według niego nie jest żadnym argumentem przeciw prawdziwości Jego człowieczeństwa, lecz dowodem na Jego bóstwo. Innym elementem teologii wcielenia Justyna jest doktryna o wcieleniu się całego Logosu. Podczas gdy w ludziach jest obecny tylko częściowo Logos spermatikos, w Chrystusa wcielił się cały Logos (I Ap. 10, 8; Dial. 100, 4). W tym tekście zawarte są dwa bardzo ważne elementy: wcielony Chrystus jest całym Logosem, Logos stał się całym człowiekiem, czyli ciałem, duszą i duchem.

Wcielenie Logosu więc to nie tylko przyjęcie ciała ludzkiego, ale całej natury ludzkiej. Antropologia Justyna inspiruje się wyraźnie tradycyjną antropologią tamtych czasów, widzącą w człowieku trzy zasadnicze elementy. Niesłusznie uważa się Justyna za prekursora apollinaryzmu, ponieważ nigdzie nie stwierdza, że Logos zajął w Chrystusie miejsce duszy rozumnej. Nasz autor w ogóle nie zastanawia się nad relacją pomiędzy bóstwem i człowieczeństwem w Chrystusie. Poprzestaje na stwierdzeniu, że był On Bogiem i człowiekiem. Jedyne podobieństwo z apollinaryzmem, to odwołanie się właśnie do trychotomicznej antropologii. To jednak żaden zarzut.

Kolejny aspekt Justyna teologii wcielenia to polemika antydoketyczna. Podkreśla on wyraźnie, że Chrystus, choć był co prawda innym od pozostałych ludzi, gdyż jego krew pochodziła z mocy Bożej, a nie z rasy ludzkiej, był jednak

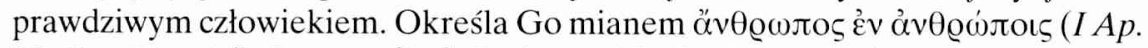

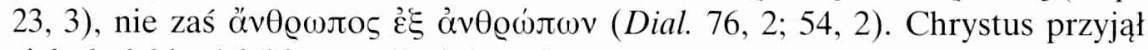
ciało ludzkie dzięki mocy Bożej, Dziewica zaś była narzędziem w całym procesie przyjmowania przez Niego ciała. Logos przyjął nie tylko człowieczeństwo, ale stał się istotą ludzką. Justyn również wielokrotnie podkreślał, że człowieczeństwo Chrystusa było prawdziwym człowieczeństwem. Podstawowym argumentem, do jakiego się odwołuje, są oczywiście wydarzenia z Jego ziemskiego życia: był poddany cierpieniom (ómoı $\alpha \theta \dot{n} \varsigma$ II Ap. 10, 8; Dial. 48, 3), wzrastał w latach, odżywiał się (Dial. 84, 2), czuł naprawdę strach przed śmiercią (Dial. $103,8)$. Jednocześnie na różnych etapach swojego ziemskiego życia Jezus posiadał pełnię mocy jako Logos.

Z perspektywy późniejszego rozwoju myśli teologicznej Justyna nauka o wcieleniu może się wydawać mało wyrafinowana i niekompletna. Musimy jednak ciągle pamiętać, że był on prekursorem nie tylko w obronie przed zagrożeniami z zewnątrz, ale także w pozytywnej wykładni wiary chrześcijańskiej. A niebezpieczeństw było po drodze wiele. Neoplatonizm, a zwłaszcza nauka o Logosie, mogły łatwo stać się Scyllą prowadzącą do „rozbicia” pełnego człowieczeństwa Chrystusa, z drugiej zaś strony, Charybda, czyli wydarzenia najbardziej ludzkie z życia Jezusa zdawały się przeczyć Jego bóstwu. Justyn zachował trwałe przekonanie wiary Kościoła II wieku, że Jezus Chrystus jest Bogiem i człowiekiem. Chyba tylko dzięki wyjątkowej asystencji właśnie Ducha Świętego, którego działania i natury Justyn do końca jeszcze nie pojmował, 
zdołał uniknąć rozbicia się o nęcąco wyglądające rafy koralowe jak doketyzm, ebionici, gnostycyzm czy marcjonizm.

\section{NAUKA O WCIELENIU W HOMILII PASCHALNEJ MELITONA Z SARDES}

Najstarsze informacje jakie posiadamy o osobie Melitona pochodzą z Listu biskupa Polikratesa Efezu do papieża Wiktora przekazanym nam przez Euzebiusza $^{78}$. Meliton był prawdopodobnie celibatariuszem i ,prorokiem”, tzn. człowiekiem duchowym, choć nie montanistą. Również według Euzebiusza, był on biskupem kościoła w Sardes, znanym już za czasów Antonina Piusa (138-161), zaś szczyt jego działalności przypadałby na okres panowania Marka Aureliusza, kiedy to napisał swoją Apologię ${ }^{79}$. Z licznych jego dzieł, wzmiankowanych przez Euzebiusza, do naszych czasów dotarły tylko fragmenty Apologii, oraz Homilia Paschalna odkryta przez B. Campbell w 1940 r. i szczątki innych, przypisywanych mu pism. ${ }^{80}$ Specjaliści na podstawie badań porównawczych papirusów greckich oraz tłumaczeń tekstu doszli do wniosku, iż tekst odkryty przez Campbella jest traktatem Melitona wzmiankowanym przez Euzebiusza. Powszechnie datuje się jego powstanie na okres pomiędzy 160 a 170 rokiem. Obecne analizy nauki Melitona o wcieleniu będą się koncentrować zasadniczo tylko na Homilii, gdyż tylko tam pojawia się ta tematyka. ${ }^{81}$

Centralną tematyką tego tekstu, określanego umownie homilią, jest typologiczna interpretacja Starego Testamentu. Wychodząc od typologii baranka paschalnego $\mathrm{Wj}$ 12, 1-32 autor interpretuje typologicznie również inne wydarzenia biblijne jako przygotowanie do ostatecznej realizacji Bożego planu zbawienia w Chrystusie. Izrael zaś, odrzucając Chrystusa, sam zostaje odrzu-

${ }^{78}$ Por. HE V 24, 1-7, SCh 41, 67-69, POK 3, 239-240.

79 Por. HE IV 13,8; IV 13,8; IV 26,1-14.

${ }^{80} \mathrm{Na}$ temat Melitona z Sardes - zob. wstęp ks. M Starowieyskiego do polskiego przekładu Homilii Paschalnej A. Świderkówny w: Pierwsi Świadkowie. Pisma Ojców Apostolskich, BOK 10, Kraków 1998, s. 300-304 a także wstęp do: Méliton de Sardes, Sur la Pâque et Fragments, wstęp, tekst krytyczny, thum. francuskie i przypisy O. Perler, SCh 123, Paris 1966, s. 8-51.

81 Bardzo wyraźne odniesienie do wcielenia znajdujemy w traktacie $O$ wcieleniu Chrystusa, przypisywanym przez niektórych badaczy Melitonowi, a cytowanym nam przez Anastazego Synaickiego (PG 89, 228D-229B). O. Perler zdecydował się dołączyć zachowany fragment w wydaniu Méliton de Sardes, Sur la Pâque. Introduction, texte critique, traduction et notes, SCh 123, 226-227. Tekst jest bardzo ciekawy, gdyż autor przypisuje Chrystusowi posiadanie dwóch substancji (ov̉oía): boskiej i ludzkiej. Byłoby to niewątpliwie jedno z najstarszych świadectw na odniesienie terminu oủoía do natur Chrystusa w literaturze chrześcijańskiej. Pozostają jednak wciąż poważne wątpliwości czy rzeczywiście Meliton jest autorem tego pisma, choć wśród jego dzieł wylicza je M. Geerard, CPG I 1093. Termin oủoi $\alpha$ kojarzy nam się raczej z okresem nicejskim i nie posiadamy świadectw jej użycia w II wieku. 
cony, otwierając w ten sposób drogę do zbawienia poganom. Meliton dzięki interpretacji typologicznej odzyskuje Stary Testament dla chrześcijan wbrew Marcjonowi i jego zwolennikom, podkreśla realność wcielenia przeciwko doketom oraz podobnie jak autor Listu Barnaby i Justyn, przedstawia jednocześnie pozytywną wizję ekonomii zbawienia (stworzenie człowieka, grzech, przygotowanie zbawienia, Chrystus zbawiający Kościół zbawiający). ${ }^{82}$ Powszechnie przyjmuje się podział dzieła na następujące części: prolog (1-10), typologia Paschy żydowskiej (11-71), niewdzięczność Izraela (72-99) i epilog (100-105).

Jeśli chodzi o wcielenie, to słusznie zauważa ks. M. Starowieyski, iż „cała Homilia przeniknięta jest prawdą o wcieleniu Chrystusa, który przyoblekł się w ludzkie ciało, o Jego dziele odkupienia człowieka przez śmierć i Mękę, o Jego zwycięstwie przez Zmartwychwstanie". ${ }^{83}$ Choć całe dzieło Melitona jest w pewnym sensie o tajemnicy wcielenia, rozumianej jako element kluczowy odkupienia, nie oznacza to jednak, iż nie posiadamy fragmentów Homilii gdzie ta tematyka jest zaprezentowana wyraźniej. Warto przy tym zauważyć, że choć Meliton interpretuje zasadniczo typologicznie Stary Testament, to jednak proroctwa dotyczące wcielenia odnosi dosłownie do Chrystusa. Ponadto, prezentacja tematyki wcielenia jest podporządkowana centralnemu tematowi, czyli śmierci i zmartwychwstaniu Chrystusa; wreszcie, interesujące nas fragmenty są rozrzucone po całym tekście i ze względu na deklamacyjny charakter Homilii, pozostawione bez jakiegokolwiek komentarza. Obecna prezentacja będzie się koncentrować na dwóch grupach tekstów: ogólne określenia o przyjęciu przez Syna Bożego kondycji ludzkiej i przyjęcie ciała z Dziewicy.

1. Syn Boży przyjął ludzką naturę. Pierwszym interesującym nas fragmentem jest następująca wypowiedź: ,zamiast baranka Bóg przyszedł, i zamiast owcy człowiek, a w człowieku Chrystus, który ogarnie wszystko". 84 Meliton argumentuje tutaj przeciwko gnostykom i marcjonitom przyjmując wyraźnie istnienie dwóch natur w Chrystusie: boską i ludzką. Realizm wcielenia wyrażony jest za pomocą porównania baranek-Bóg, owca-człowiek, w człowiekuChrystus. Baranek w licznych tekstach Starego Testamentu posiada znaczenie i symbolikę mesjanistyczną, a w jednym z fragmentów przypisywanych Meli-

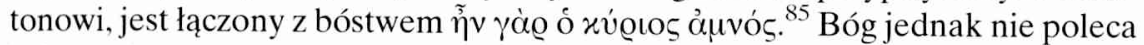
już składać na ofiarę baranka, lecz posyła w tym celu swego Syna. Druga część jest trudniejsza do interpretacji. Jezus nigdzie w Nowym Testamencie nie jest

${ }^{82}$ Por. M. Starowieyski, Tajemnica Bożego planu zbawienia-Meliton z Sardes, BOK 10, 300-

304; O. Perler, Introduction, SCh 123, 7-51.

83 Tajemnica Bożego planu, s. 303.

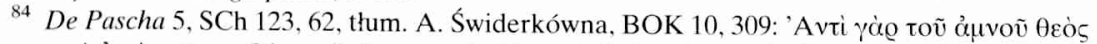

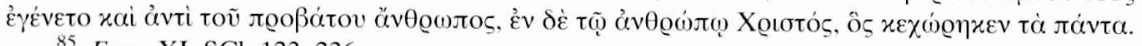

85 Frag. XI, SCh 123, 236. 
określany terminem $\pi \varrho o ́ \beta \alpha \tau o v .{ }^{86} \mathrm{Nie}$ bardzo wiadomo więc, do czego odnosi się to porównanie. Wreszcie $\mathrm{w}$ trzecim członie Meliton daje wyraz swemu przekonaniu, iż to właśnie człowieczeństwo stało się „narzędziem” objawiania mesjańskiej tożsamości Jezusa.

Również w rozdziałach 8-9 Homilii odnajdujemy wyraźne stwierdzenia naszego autora o posiadaniu przez Chrystusa natury boskiej i ludzkiej. Ten, który został „zrodzony jak Syn” i ,pogrzebany jak człowiek, powstał z mar-

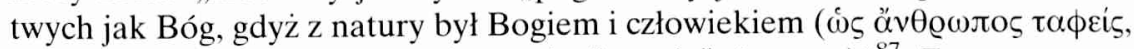

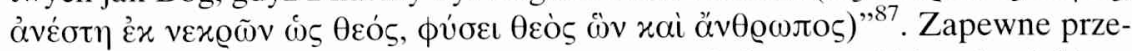
ciwko doketom Meliton podkreśla, że Chrystus był rzeczywiście człowiekiem, ponieważ został pogrzebany: $x \alpha \theta^{\prime}$ ó $\theta \alpha \dot{\pi} \tau \varepsilon \tau \alpha \iota ~ \alpha ̊ v \theta \varrho \omega \pi o \varsigma^{88}$. Inna rzecz zasługuje jednak w tym tekście na uwagę, a mianowicie fakt, że używa terminu фúøı na określenie dwóch natur w Chrystusie. Trzeba przyznać, iż jak na II wiek, jest to wyjątkowo precyzyjna terminologia chrystologiczna.

W rozdz. 47 Homilii Meliton, znowu przeciw doketom podkreśla, że „Pan przyszedł na ziemię: aby przyoblekłszy się w cierpiącego wyniósł go na wyżyny niebieskie" ${ }^{89}$ Realizm wcielenia i cierpień Chrystusa jest tutaj wyrażony określeniem ,przyoblekłszy się w cierpiącego”, tzn. w człowieka Śmiertelnego. Idea ta powraca także w rozdz. 100 naszego tekstu: „Pan przyoblekł się w człowieka

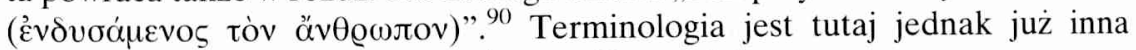
i nawiązuje do tej, jako została użyta w 66 rozdziale.

Podsumujmy tę część analiz. Meliton w żadnym z przytoczonych tekstów nie mówi o wcieleniu Logosu. W kontekście antydoketycznym akcentuje przyjęcie przez Chrystusa rzeczywistej kondycji człowieka śmiertelnego, potwierdzonej właśnie przez Jego cierpienia. Przeciwko gnostykom i marcjonitom przyjmuje istnienie w Chrystusie dwóch natur: boskiej i ludzkiej, i jest jednym z pierwszych pisarzy chrześcijańskich, używających terminu фúoı na ich określenie. Podobnie jak Justyn, rozumie wcielenie jako przyjęcie całej kondycji ludzkiej, a nie tylko ciała ludzkiego.

2. Przyjąl ciało i narodzil się z Dziewicy. Pierwszym tekstem, w którym Meliton nawiązuje do poczęcia Chrystusa w łonie Dziewicy jest rozdz. 66 Homilii. Nasz autor od tego właśnie rozdziału rozpoczyna argumentację mającą na celu pokazać realizację zapowiedzi starotestamentalnych. I choć tematyka wcielenia pojawia się tutaj jakby tylko przejściowo, ponieważ ekspozycja koncentruje się na cierpieniu Chrystusa, niemniej jednak jest ona potraktowa-

86 Por. O. Perler, Notes, SCh 123, 136.

87 De Pascha 8, SCh 123, 64, BOK 10, 309.

88 Tamze, 9, SCh 123, 64.

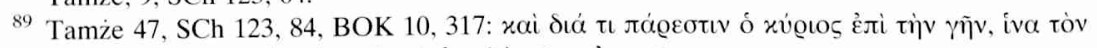

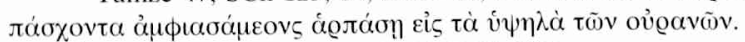

90 Tamże 100, SCh 123, 120, BOK 10, 329. 
na zdecydowanie szerzej niż np. w rozdz. 47. Oto interesująca nas pierwsza część tekstu:

„To On przybył z nieba na ziemię dla tego, który cierpiał, w niego się też przyodział w łonie Dziewicy, skąd wyszedł człowiekiem". ${ }^{91}$

Meliton ujmuje wcielenie jako proces w trzech etapach: przybycie Pana na ziemię, przyodzianie się w naturę człowieka cierpiącego w łonie Dziewicy, ukazanie się jako pełny człowiek przez narodzenie. ${ }^{92}$ Biskup Sardes podaje również motywację soteriologiczną zstąpienia na ziemię ,dla tego, który cierpiał”, czyli dla człowieka. Kontekst tych wypowiedzi jest znowu wyraźnie antydoketyczny, gdzie rzeczywiste cierpienia Chrystusa są dowodem prawdziwości Jego człowieczeństwa. Schemat prezentacji jest jednak także typowo biblijnym schematem uniżenia - wywyższenia, obecnym choćby w Flp 2, 6-11, a rozwiniętym później przez Arystydesa ${ }^{93}$ i Justyna ${ }^{94}$. Wyjątek stanowi tutaj brak odniesienia o powrocie do nieba, obecny choćby w rozdz. 47. Warto zauważyć, że na opisanie zstąpienia Chrystusa na ziemię, Meliton nie używa

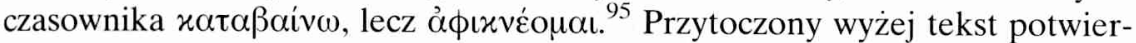
dza także, iż odróżnia on dziewicze poczęcie od momentu narodzenia Chrystusa. Dziewicze poczęcie opisuje jako przyodzianie się w cierpiącego człowieka w łonie Dziewicy. I choć nie wzmiankuje nic o roli Ducha Świętego, to sam fakt przyodziania się w człowieka w łonie właśnie Dziewicy, niejako zakłada Jego udział. Meliton, jako jedyny przedstawia moment poczęcia się Chrystusa za pomocą czasownika દ́voúw. ${ }^{96}$ To Jego przyoblekanie się

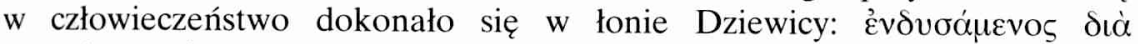

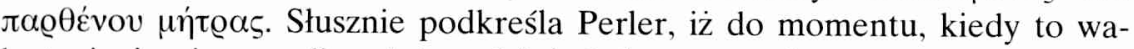
lentynianie nie zaczęli nadużywać $\delta \iota \dot{\alpha}$, było ono preferowane przez pisarzy wczesnochrześcijańskich. Tak jest również w przypadku Melitona. Dlaczego tak było? Być może dlatego, iż akcentowano w ten sposób kluczową rolę Boga w dziewiczym poczęciu Mesjasza, widząc Maryję jako „narzędzie” realizacji Jego planów. $\Delta ı \dot{\alpha}$ posiada w naszym tekście znaczenie wyraźnie instrumentalne, a sens całego określenia byłby następujący: ,przyoblekł się też w niego poprzez/za pośrednictwem łona Dziewicy". W ten sposób wyrażony został zarówno realizm wcielenia, jak również pośrednictwo Dziewicy.

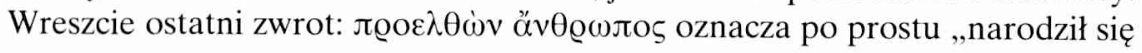

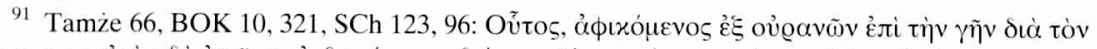

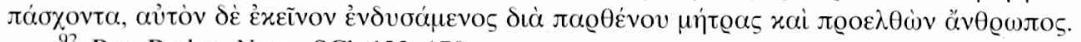

92 Por. Perler, Notes, SCh 123, 170.

93 Por. Apologia 15,4.

${ }^{94}$ Por. Dialogus 45,4; 64,7 i Perler, Notes, SCh 123, 170.

95 Por. R. Popowski, Wielki Stownik Grecko-Polski, s. 86; H. G. Liddell - R. Scott, A GreekEnglish Lexicon, s. 290.

96 Por. E. Goodspeed, Index Apologeticus, s. 103. 
jako człowiek". ${ }^{97}$ Podkreślmy, że znowu chodzi tutaj o człowieka, a nie tylko o ciało. Meliton porusza się więc tutaj wyraźnie w obrębie schematu chrystologicznego Logos-anthropos, a nie tylko Logos-sarx.

Drugim tekstem traktującym o tematyce wcielenia jest miejsce, gdzie Meliton wymienia elementy charakteryzujące ziemskie życie Chrystusa: przyjęcie ciała z Dziewicy, śmierć na krzyżu, pogrzebanie w ziemi, powstanie $\mathrm{z}$ martwych i wniebowstąpienie. Interesujący nas pierwszy element brzmi

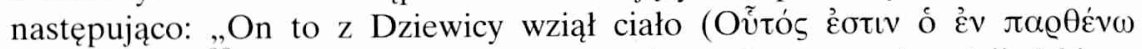

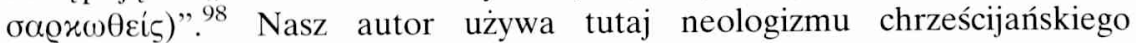

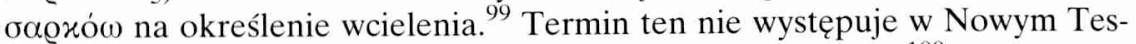
tamencie ani w pismach Ojców Apostolskich czy Apologetów. ${ }^{100}$ Widzieliśmy

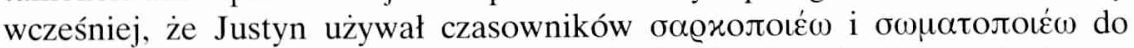
wyrażenia wcielenia Chrystusa, które jednak nie cieszyły się aż tak dużym powodzeniem u następnych teologów chrześcijańskich. Termin Melitona jest absolutnym novum na wyrażenie tajemnicy Wcielenia i wszedł na stałe do chrześcijańskiej terminologii symbolów wiary. Widzimy go zastosowany choć-

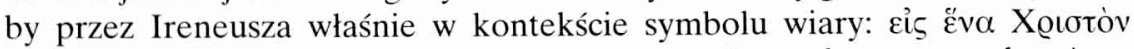
'I

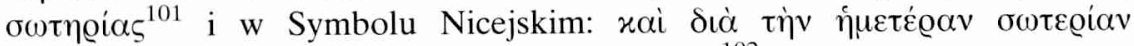

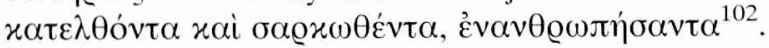

W rozdziale 71 Homilii znajdujemy ciekawe, lecz jednocześnie trudne do interpretacji stwierdzenie: „On to narodził się z Maryi, pięknej owieczki (Oữó tekst Melitona, w którym pojawia się imię Maryi w opisie wcielenia. Kontekst tego wyrażenia jest zdecydowanie antydoketyczny, gdzie realizm wcielenia zostaje wyrażony za pomocą $\dot{\varepsilon} x$, a nie $\delta ı \grave{\alpha}$, jak w rozdz. 66. Wreszcie $\tau \varepsilon \chi \theta \varepsilon i \varsigma$ nawiązuje do terminologii ewangelicznej, opisującej narodzenie Chrystusa (Mt 1,25; k 2,6-7). Oprócz imienia Maryi pojawia się w tekście

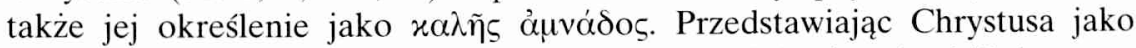
baranka paschalnego, Meliton używa metafory „pięknej owieczki” do wyra-

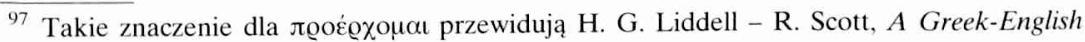
Lexicon, s. 1479.

98 De Pascha 70, SCh 123, 98, BOK 10, 322

99 Pojawia się on, co prawda, w pismach niechrześcijańskich por. H. G. Liddell - R. Scott, A Greek-English Lexicon, s. 1585.

${ }^{100}$ Por. E. Goodspeed, Index patristicus sive Clavis Patrum Apostolicorum operum, Peabody 1993; w Index Apologeticus, Leipzig 1912, Goodspeed nawet nie uwzględnia tego terminu u Melitona.

101 Adversus haereses I 10, 1, SCh 264, 155.

102 Symbolum Nicaenum, w: Bibliothek der Symbole und Glaubensregeln der Alten Kirche, Hildesheim 1962, 161

103 De Pascha 71, SCh 123, 98, BOK 10, 323. 
żenia dziewictwa Maryi. Myśl tę rozwiną później Epifaniusz i Cyryl Aleksandryjski, a także liturgia bizantyjska Wielkiego Piątku i Wielkiej Soboty. ${ }^{104}$

Ostatnim wreszcie tekstem Homilii, gdzie Meliton nawiązuje do tematyki wcielenia jest rozdział 104: „On przyjął ciało z Dziewicy (ó દ̉v $\pi \alpha \varrho \theta \dot{\varepsilon} v \omega$ $\sigma \alpha \varrho \varkappa \omega \theta \varepsilon i \zeta) "{ }^{105}$ Określenie to jest powtórzeniem znanego nam już zwrotu z omawianego rozdz. 70. Wcielenie jest tutaj wyrażone za pomocą znanego nam neologizmu chrześcijańskiego Melitona. Ostatnie teksty pokazują, że biskup Sardes bardzo wyraźnie mówił o tym, że Syn Boży stał się człowiekiem, nie zaś jedynie ciałem ludzkim. Moglibyśmy powiedzieć, że w swojej ekspozycji stosuje schemat Logos-anthropos. Niemniej jednak podkreśla również jednoznacznie przyjęcie przez Chrystusa rzeczywistego ciała ludzkiego,

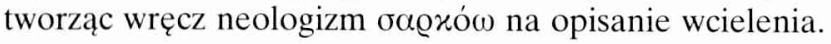

\section{L'INCARNAZIONE DI CRISTO NELLA RIFLESSIONE TEOLOGICA DEGLI APOLOGISTI GRECI DEL II SECOLO}

(Sommario)

Le analisi sopra condotte ci hanno fatto vedere chiaramente che il II secolo era nonostante tutto un periodo molto fecondo della riflessione cristiana sul mistero dell'incarnazione del Figlio di Dio. Lo schema dominante dell'esposizione di questa tematica, salvo Aristide, è stato quello chiamato comunemente Logos-anthropos completato nel contesto della polemica contro il docetismo con quello Logos-sarx. In modo esplicito veniva espressa anche la fede nella nascità verginale di Gesù Cristo.

Aristide nella sua Apologia utilizzando probabilmente la regula fidei del tempo

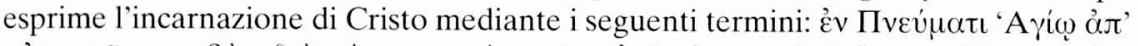

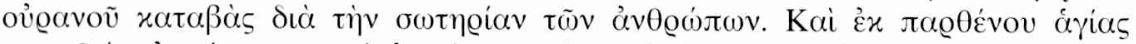

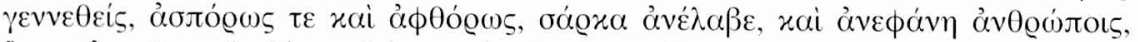

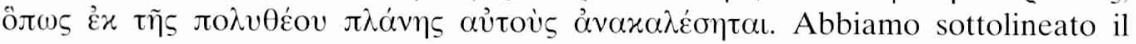
ruolo dello Spirito Santo ( $\dot{\varepsilon} v$ - mediante) in questa missione del Figlio di Dio che discende dal cielo per la salvezza degli uomini, che ha voluto essere concepito e nato da una donna vergine però in modo diversi da tutti altri gli uomini cioè senza la partecipazione di un uomo. Egli ha assunto la carne umana e si è rivelato agli uomini perchè rinunciassero all'errore del politeismo e credessero nell'unico e vero Dio.

Nei testi di Giustino si notano chiaramente tre filoni di riflessione. Tutto il Logos ha assunto la natura umana, cioè corpo, anima e spirito. Giustino insiste sul fatto che

\footnotetext{
104 Por. O. Perler, Notes, SCh 123, 176-177.

105 De Pascha 104, SCh 123, 124, BOK 10, 330.
} 
Logos è diventato l'uomo, quindi esprime la sua riflessione a proposito dentro schema Logos-anthropos. Sottolinea però anche che Cristo ha assunto la vera carne umana, veramente patì ed ebbe paura della morte. Proprio in quel contesto Giustino

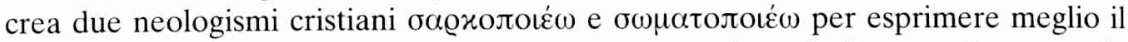
mistero dell'incarnazione. Infine il terzo elemento riguarda il concepimento e la nascità verginale di Gesù. Secondo Giustino Dio è stato l'agente principale dell'incarnazione di Cristo e Maria invece soltanto lo strumento, però tutto questo non mette in dubbio la sua vera umanità. Per il nostro apologeta la natura divina ed umana di Cristo sono il punto di partenza fondamentale di ogni riflessione cristologica.

Melitone di Sardes, così come Giustino, esprime la sua riflessione sull'incarnazione in Peri Pascha principalmente secondo lo schema Figlio di Dio-anthropos completandola con quello Figlio di Dio-sarx contro i doceti. Anche lui per descri-

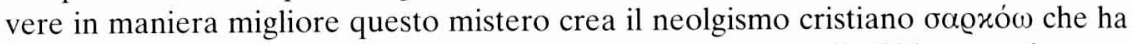
avuto la fortuna di entrare nella terminologia tradizionale della Chiesa grazie p. es. al Concilio di Nicea. Vescovo di Sardes sottolinea pure la nascità verginale di Cristo da Maria.

Se si volesse descrivere in poche parole la riflessione degli apologisti greci del II secolo sull'incarnazione di Cristo, essa potrebbe essere riassunta così: Figlio di Dio/ Logos è diventato veramente l'uomo, ha assunto la vera carne umana ed è nato da una vergine. 